\title{
The Dispensable Lives of Soldiers
}

\section{Citation}

Gabriella Blum, The Dispensable Lives of Soldiers, 2 J. Legal Analysis 69 (2010).

\section{Published Version}

http://jla.oxfordjournals.org/content/2/1/115.full.pdf

\section{Permanent link}

http://nrs.harvard.edu/urn-3:HUL.InstRepos:10880555

\section{Terms of Use}

This article was downloaded from Harvard University's DASH repository, and is made available under the terms and conditions applicable to Open Access Policy Articles, as set forth at http:// nrs.harvard.edu/urn-3:HUL.InstRepos:dash.current.terms-of-use\#OAP

\section{Share Your Story}

The Harvard community has made this article openly available.

Please share how this access benefits you. Submit a story.

\section{Accessibility}




\title{
THE DISPENSABLE LIVES OF SOLDIERS
}

\author{
Gabriella Blum?
}

\section{ABSTRACT}

Why are all soldiers fair game in war? This paper challenges the status-based distinction of the laws of war, calling instead for revised targeting doctrines that would place further limits on the killing of enemy soldiers. I argue that the changing nature of wars and militaries casts doubts on the necessity of killing all enemy combatants indiscriminately.

I offer two amendments: The first is a reinterpretation of the principle of distinction, suggesting that the status-based classification be complemented by a test of threat. Consequently, combatants who pose no real threat would be spared from direct attack. The second is a reinterpretation of the principle of military necessity, introducing a least-harmful-means test, under which an alternative of capture or disabling of the enemy would be preferred to killing whenever feasible.

I discuss the practical and normative implications of adopting these amendments, suggesting possible legal strategies of bringing them about.

\section{INTRODUCTION}

In 1951, the U.S. naval command struck the Kapsan compound in North Korea, where Chinese and North Korean officials were attending a meeting (Peebles 2005, 79). The surprise attack destroyed the entire camp, killing an estimated 510-530 Chinese and North Korean personnel, including 144 party officials (Pontrelli 2007, 64-65; Reynolds 2005, 463), and obliterated the archives of the North Korean Communist Party (Peebles 2005, 80).

1 Assistant Professor of Law, Harvard Law School. I am grateful to Ken Anderson, Yishai Beer, Rachel Brewster, Glenn Cohen, Jack Goldsmith, Jim Greiner, Moshe Halbertal, Stephen Holmes, Sam Issacharoff, Asa Kasher, Adriaan Lanni, Daryl Levinson, Larry May, Gerry Neuman, Ben Sachs, Roy Schondorf, Jed Shugerman, Matthew Stephenson, Roberto Unger, and Adrian Vermeule and the reviewer for the Journal of Legal Analysis for their helpful comments, suggestions, and debates. I also thank the participants of the Harvard Law School faculty workshop and of the Just and Unjust Wars seminar at NYU Law School for their engagement with this piece. Natalie Lockwood provided outstanding research assistance and contributed her own thoughts and suggestions. All errors are mine. 
The outraged Communist broadcasts on Radio Pyongyang put a price on the heads of the Navy pilots, referring to them as the "butchers of Kapsan"a term proudly adopted thereafter by the Navy itself (Pontrelli 2007, 60-66). In 1991, the U.S. military pounded with airstrikes and gunfire a convoy of Iraqi troops retreating from Kuwait. Although the ultimate death toll was lower than the initial reports of thousands of casualties (Heidenrich 1993), reporters who arrived on the scene "recorded the carnage that stretched along that road for miles, producing gut-wrenching images of charred bodies in the blackened hulks of bombed-out vehicles. Trucks, personnel carriers, and hundreds of civilian vehicles lay strewn along the road," a road they later dubbed "the Highway of Death" (Waller \& Barry 1992, 16). Military officers were reported to be "sickened by what they saw" (Waller \& Barry 1992, 16). In 1993, Bosnian-Serb soldiers fired mortar rounds at Bosnian soldiers playing soccer on an improvised neighborhood field, killing and injuring civilian spectators nearby. The International Criminal Tribunal for the Former Yugoslavia found the Bosnian-Serb commanders guilty of harming civilians, but found no legal violation in the targeting of the sporting soldiers. ${ }^{2}$ In 2008, Israel struck an entire group of Palestinian police cadets (on the theory that they were part of the Hamas forces), while they were marching in their graduating ceremony, killing scores (Colvin, Allen-Mills, \& Mahnaimi 2008). The number of Taliban, Al Qaeda, and other insurgent groups' members who have been killed by Coalition forces in Afghanistan is estimated at over 22,000. Coalition casualties are around 1,200.

Much of the criticism of how countries fight wars goes to the question of how many civilian casualties their military operations inflict. Almost none goes to how many combatant casualties they inflict. For those parties who engage in propaganda wars over "hearts and minds" of both domestic and international public opinion, the tendency is to exaggerate the number of one's own civilian casualties and, correspondingly, minimize the number of one's own combatant casualties. Civilian casualties are illegal, immoral, and unjust. Combatants, as a matter of international law, are fair game. All combatants are fair game. But why should this be so? This paper suggests that it should not be, and that the prevailing legal perspective, which accepts the unlimited and indiscriminate killing of soldiers, is less justifiable than is commonly held.

2 Prosecutor v. Galic, Case No. IT-98-29-A (Nov. 30, 2006). 
In Just and Unjust Wars, Michael Walzer ([1977] 2006, 143) famously 3 takes on the question of the Naked Soldier, first raised by Robert Graves (1929) in his memoir Good-bye to All That: Is a soldier stripped naked and swimming in the lake a legitimate target during an armed conflict? The answer, says an uncomfortable Walzer, is unequivocally "yes."

The existing interpretation of the laws of war supports Walzer's conclusion. The principle of military necessity allows parties to a conflict to use all necessary lawful force to achieve their goals. The foundational principle of distinction, often heralded as the humanitarian pillar of the laws of war, grants immunity to civilians. Together, the two principles sum up the tradeoff that the law seeks to induce-sacrificing the lives of soldiers to protect the lives of civilians. Soldiers are allowed to kill enemy soldiers, with few limitations; in exchange for the right to fight and kill others, they assume the risk of being killed themselves. Civilians, on the other hand, must not partake in hostilities, and if they do, may be punished (and under some circumstances, targeted); in return for their abstention from fighting, they enjoy immunity from deliberate attack and must be protected to the extent possible. The laws of war are, thus, status-based: One is either a civilian or a combatant; once identified as one or the other, one is subject to the privileges and obligations that the laws prescribe for each group.

The additional fundamental principles of the laws of war-namely, humanity (which forbids the use of means and methods of warfare that cause superfluous injury or unnecessary suffering) and proportionality (which calls for the minimization of civilian casualties) — have all been interpreted in ways that do not add much limitation on the right to kill enemy soldiers. In fact, other than some limitations on the types of weapons that can be employed to kill enemy combatants, the legal rules that apply to the fate of soldiers on the battlefield are still much the same as they were in the nineteenth century. Soldiers are legitimate targets when they are asleep in their barracks, swimming in the lake, retreating, and probably when they are on leave. ${ }^{3}$ There is no duty to offer enemy combatants surrender or to warn them in advance of attack, nor is there a duty to try to apprehend them

3 See Yoram Dinstein $(2007,144)$ : “As far as ordinary combatants are concerned, it must be perceived that they are running a risque du métier. They can be attacked (and killed) wherever they are, in and out of uniform, even when they are not on active duty. There is no prohibition either of opening fire on retreating troops (who have not surrendered) or of targeting individual combatants." 
alive. There is no difference between volunteers or conscripts, between those fighting just or unjust wars, or between those fighting for democratic or nondemocratic regimes. The only general limitation on the killing of enemy combatants is once the latter are rendered hors de combat, through capture, surrender, or incapacitating injury.

A vast literature in both law and philosophy has been dedicated to the protection of civilians in war, inquiring into the rationale behind noncombatant immunity, the extent to which the immunity applies, its translation onto various theaters of war, and the conditions under which it is lost. Special attention has been accorded to civilians on the modern battlefield, namely in wars of terrorism and insurgency, where distinguishing between civilians and combatants is more problematic both in terms of identification (for the lack of military uniform) and in terms of the function and role each group plays.

The striking feature of the mainstream literature is its general acceptance (albeit at times, with some moral discomfort) of the near-absolute license to kill all combatants and of the law's view of combatants as nothing more than instruments of war. Moreover, although some discussions of the principle of distinction in the context of the war on terrorism have called for narrowing the scope of civilian immunity, these discussions have not been accompanied by any calls for correspondingly narrowing the scope of combatant targetability. The outcome has been that, overall, more individuals have become potentially susceptible to intentional killing in war.

Only a handful of scholars, most notably philosophers Larry May (2007, 108-117) and more recently Asa Kasher (2009a), have challenged this mainstream view of the dispensable lives of soldiers. Each relying on his own perception of concepts of humanity, dignity, or compassion, both ultimately conclude that soldiers who do not pose a real threat at a certain place and time should be spared. In a discussion limited to asymmetrical warfare, Paul Kahn $(1999,2002)$ suggested that where there is a gross asymmetry in power, war turns into a police-enforcement operation, which should focus only on the guilty/threatening, and not on others. Adam Roberts (2008) has suggested seeking ways to compel the enemy government to surrender rather than killing as many of its soldiers as possible. Recently, also, the International Committee of the Red Cross (in the course of a study dedicated to civilian immunity) suggested that the license to kill enemy combatants should be narrowed by a functional test of how 
necessary this killing is (Melzer 2009, 77-82). ${ }^{4}$ This suggestion remains a nonbinding "interpretive guidance," which, as the ICRC report itself notes, has been met with resistance on the part of the experts who participated in the study (Melzer 2009, fn. 221).

This article suggests that beyond any moral stance or a recommended interpretive guidance, there is a case to be made that the legitimate scope of combatant targetability should be narrowed as a matter of legal obligation, one that would be incorporated into the military's rules of engagement.

The laws of war have developed with evolving moral perceptions and strategic geopolitical and military developments. I study the moral justifications offered for combatant targetability, and join May and Kasher in challenging the enduring rationale of the class-based distinction between civilians and combatants. I then turn to examine the changing nature of wars and of combatants, questioning the strategic arguments in favor of maintaining combatant targetability. I argue that changes in the ways wars are fought and won, in the roles of soldiers in militaries, in the civilianization of the armed forces, and in technological capabilities, cast doubt on the extent to which the killing of as many enemy combatants as possible is either necessary or sufficient to end wars. Once the military benefit of killing as many enemy soldiers as possible is diminished (even though not eliminated), the legal permission to do so can no longer be easily justified under the principle of military necessity; instead, it threatens to become exorbitant cruelty.

Undoubtedly, war is about killing, and mankind has yet to imagine wars without death. The argument here does not engage with the question of whether killing in the short run preserves more lives later on. ${ }^{5}$ The laws of war restrict themselves to tactical calculations-minimizing cruelty in particular engagements - rather than focusing on overall calculation of the "body count" of the war; were it not so, any and all humanitarian limitations on the conduct of war could be done away with on the theory that they only make war more bearable, possible, and perhaps even attractive. Accordingly, I limit my argument to claim that by making all killing of enemy soldiers "legal," the laws of war make belligerent parties more callous

4 The subject of combatant targetability occupies six out of over eighty pages of the report.

5 For a discussion about the limiting rules of international humanitarian law (IHL) and the possibility of breaking them to preserve more lives, see Gabriella Blum (2010). 
about some of the war's human costs. ${ }^{6}$ If we believe that all lives have an affirmative value, then limiting the permissibility of killing enemy soldiers is a worthy task.

In suggesting a possible alternative reading of the laws of war, the greatest challenge is one of manageability. The obvious advantage of the existing paradigm has been its purportedly straightforward applicability to the battlefield: In reliance on a status-based rule of distinction, soldiers need not engage in a costly and dangerous process of ascertaining the merits of each individual target. Any alternative rule for permissible targeting that requires more fine-grained distinctions among combatants would raise the costs of decision-making, training, and monitoring of compliance. These increased costs would have to be weighed against the value of human lives.

Moreover, given the changing nature of the battlefield, the current class-based paradigm itself is becoming increasingly dependent on caseby-case judgments. The reality of a mixed combatant-civilian population within and outside the battlefield, coupled with a growing humanitarian conscience that is sensitive to civilian casualties, already requires states to invest in military technologies that enable them to tell combatants apart from civilians and target the former without harming the latter. To do this, they must often engage in individual-based determinations of the identity and role of their target. Here we have a logical basis for the same action for the opposite purpose: These same capabilities that are currently used to comply with the distinction between civilians and combatants can be put to use to tell threatening combatants apart from unthreatening ones.

With these considerations in mind, the last part of the paper offers two amendments to the current doctrine of targeting combatants: The first is based on a more fine-grained application of the principle of distinction, suggesting that as a mirror-image to the presumption of civilian immunity, which is lost when the civilian takes a direct part in hostilities, the presumption about soldiers' targetability will be similarly rebuttable where a soldier poses no threat. The second suggests a re-reading of the principle of military necessity to incorporate a least-harmful-means test, mandating the capture or otherwise disabling of the enemy rather than direct targeting, wherever feasible. I discuss the challenges of applying these amendments on the battlefield and the possible legal strategies of adopting them.

6 On the numbing effects of the legal discourse of IHL norms, see David Kennedy (2006). 
Ultimately, the decision of whether or not to adopt these amendments must rest on the value we want to assign human lives, particularly those of enemy combatants.

The focus in this paper is on the combatant side of the principle of distinction, as complementing the existing scholarship that already addresses civilian immunity. I therefore largely ignore the implications of the argument for noncombatant immunity, although I intend the suggestions of limiting combatant targetability as a corollary—rather than a threat — to civilian immunity.

The article proceeds as follows. Part 2 offers an overview of the general principles of the laws of war, as they pertain to the permissible targeting of combatants on the battlefield. Part 3 summarizes the mainstream philosophical justifications for subjecting combatants to deliberate targeting and the dissenters' voices in challenging them. Part 4 fleshes out three fundamental strategic changes in the nature of wars and combatants, namely the declining value in killing generic combatants in modern conflicts, the civilianization of the armed forces, and the technological sophistication of at least some militaries. In Part 5, I propose possible alternative doctrines, which aim at limiting the legitimate targeting of combatants. I discuss the practical implications of this amended reading and the possible legal strategies for bringing it about.

\section{SOLDIERS-THE VIEW FROM THE LAWS OF WAR}

Throughout the ages, fighting on behalf of one's country/state/nation has been a concept synonymous with honor, masculinity, and patriotism. ${ }^{7}$ In Athens, military service was a duty and a privilege reserved for and incumbent upon citizens of the polis, distinguishing them from slaves or foreigners. In medieval times, the status of knighthood was reserved for the nobility (from the young age of seven), whereas footsoldiers were serfs and criminals. Only the nobility had a right to bear arms. It was for this reason that the use of the crossbow (which allowed a commoner to strike a nobleman from afar-thereby bypassing the chivalric code of combat) was prohibited (Strickland 1996, 72). ${ }^{8}$

7 On the relationship among soldiers, chivalry, and masculinity, see generally Leo Braudy (2005).

8 The prohibition, which later applied to wars among Christians, but not with "infidels," was never adhered to. 
With the development of the nation state, beginning in the fifteenth century but gaining greater force in the seventeenth century, volunteers (and mercenaries) were replaced with national standing armies. The Napoleonic wars saw mass recruits of poorly armed, poorly trained, and ill-equipped soldiers, who were sent to charge attacks by constituting a human wave, ultimately earning the label of "cannon fodder" (De Chateaubriand 1814). The development of modern national armies required reformulating the laws of war, from derivatives of notions of honor and chivalry- which befitted battles fought by privileged classes - to rules based on reciprocity and professionalism that could be generalized for mass armed forces. Military dress, although known in some form or another as early as the Spanish infantry of Hannibal and the Spartan hoplites, became more uniform and standardized, distinguishing soldiers from civilians.

Laws and customs of warfare once again became preoccupied with how armies fought each other, largely neglecting the Enlightenment era's concern for the well-being of civilians until after World War II. The religious-based justifications for restraint in war gave way to more secular, utilitarian prohibitions that corresponded to geopolitical and technological changes affecting military strategies and capabilities. Some new rules were driven by lingering remnants of medieval notions of honor and fairness on the battlefield (banning treacherous killing or masquerading as the other side's combatants), and others by the wish to reinforce the principle of distinction and protect civilians (prohibiting the practice of shielding or disguising oneself as a civilian). Specifically negotiated agreements further banned some types of weapons believed to cause unnecessary suffering (dum-dum bullets or poisonous gas).

None of these limitations, however, with the exception of the rules pertaining to hors de combat (on which I elaborate further later in the article), concerned the right to kill all enemy combatants; they only constrained how one could exercise that right by prohibiting certain means and methods of warfare. ${ }^{9}$ In effect, the rules pertaining to the permissible killing of combatants have remained much as they were in the nineteenth century.

The four basic principles of the laws of war, or as they are also knowninternational humanitarian law (IHL), are military necessity and humanity, distinction, and proportionality. In what follows, I expand on how the existing understanding of these principles allows for the permissible targeting of all combatants. 


\subsection{Military Necessity and Humanity}

As introduced into the Lieber Code of 1863 at the beginning of the American Civil War ${ }^{10}$ - the first modern codification of the laws of war-the principle of military necessity was at once both an enabling and a limiting concept. It allowed the use of "those measures that are indispensable for securing the ends of the war and that are lawful according to the modern law and usages of war." ${ }^{11}$ In Lieber's time, these measures included "all direct destruction of life and limb of armed enemies, and of other persons whose destruction is incidentally unavoidable... it allows of the capturing of every armed enemy, and every enemy of importance to the hostile government, or of particular danger to the captor; it allows of all destruction of property and obstruction of the ways and channels of traffic, travel, or communication, and of all withholding of sustenance or means of life from the enemy...."12 But alongside this comprehensive list of "Do's," military necessity had a more implied "Don't": It "does not admit of cruelty." ${ }^{13}$ This meant that destruction and pain that were not strictly "necessary" for securing the war's ends were impermissible. This limiting feature has sometimes been framed under a separate principle of humanity, according to which the means and methods of warfare that cause superfluous injury and unnecessary suffering are proscribed. ${ }^{14}$

Five years after the Lieber Code, the principles of military necessity and humanity were codified within the 1868 St. Petersburg Declaration. ${ }^{15}$ Negotiated among military officials from the various powers, the Declaration sought to "[fix] the technical limits at which the necessities of war ought to yield to the requirements of humanity," ${ }^{16}$ and stated that "the only legitimate object which States should endeavor to accomplish during war is to weaken the military forces of the enemy; that for this purpose it is sufficient to disable the greatest possible number of men." 17

10 Lieber Code, General Orders No. 100 (U.S. Adjutant General's Office 1863).

11 Id. Art. 14.

12 Id. Art. 15 (italics added).

13 Id. Art. 16.

14 See Hague Regulations Art. 22, annexed to the Convention Respecting the Laws and Customs of War on Land, Oct. 18, 1907, 36 Stat. 2277 [hereinafter Hague Convention of 1907, Hague Regulations]: "[t]he right of belligerents to adopt means of injuring the enemy is not unlimited."

15 Declaration Renouncing the Use, in Time of War, of Certain Explosive Projectiles, Nov. 29/ Dec. 11, 1868 [hereinafter St. Petersburg Declaration].

16 Id.

17 Id. (emphasis added). 
The century and a half that separates us from the St. Petersburg Declaration saw little change in the understanding of the principles of military necessity and humanity. ${ }^{18}$ The 1899 and 1907 Hague Regulations and the 1929 and 1949 Geneva Conventions added and codified rules on hors de combat (on which I elaborate later in the article) and on permissible tactics of war, while other subsequent conventions (such as the Biological Weapons Convention, the Convention on Certain Conventional Weapons, and the Chemical Weapons Convention) stipulated prohibitions on specific types of weapons that cause superfluous injury and unnecessary suffering. On the whole, however, the enabling features of "military necessity," as far as soldiers are concerned, have taken precedence over any limiting components.

In its present-day formulation, the principle of military necessity accordingly permits "only that degree and kind of force, not otherwise prohibited by the law of armed conflict, that is required in order to achieve the legitimate purpose of the conflict, namely the complete or partial submission of the enemy at the earliest possible moment with the minimum expenditure of life and resources" (UK Ministry of Defence 2004). ${ }^{19}$ "Necessity" thus justifies not only what is required to win the war, but also what reduces the risks of losses or costs of the war. ${ }^{20}$ As the ICRC itself recognizes in its Interpretive Guidance, "Apart from the prohibition or restriction of certain means and methods of warfare, however, the specific provisions of IHL do not expressly regulate the kind and degree of force permissible against legitimate military targets" (Melzer 2009, 78).

This statement is compatible with the instructions given by militaries to the armed forces on the battlefield. The U.S. Army Field Manual, for instance, accepts, as a general matter, that, "The law of war places limits on employing any kind or degree of violence that is not actually necessary for military purposes" (U.S. Dept. of the Army 2003), but in its operational section, it instructs that "Wartime ROE [Rules of Engagement—G.B.] permit U.S. forces

18 As the ICRC concedes, "Historically, the modern concept of military necessity has been strongly influenced by the definition provided in Art. 14 of the Lieber Code" (Melzer 2009, fn. 215).

19 See also U.S. Dept. of the Army (1956), U.S. Dept. of the Navy (2007), \& NATO (2009).

20 See also the decision by the American Military Tribunal in Nuremberg in the "Hostage Case," proclaiming that "Military necessity permits a belligerent, subject to the laws of war, to apply any amount and kind of force to compel, the complete submission of the enemy with the least possible expenditure of time, life, and money." USA v. List et al., 11 NMT 1230, 1253 (American Military Tribunals, Nuremberg, 1948). 
to open fire upon all identified enemy targets, regardless of whether those targets represent actual, immediate threats" (U.S. Dept. of the Army 2000). ${ }^{21}$

\subsubsection{The "Hors de combat" Exception}

The broadest exception to the general right to kill enemy combatants is the category of combatants who are hors de combat (in French, "outside the fight") - those who have been rendered incapable of fighting, through surrender, capture, or injury.

Some rules prescribing certain behavior toward the injured, captured, or dead have been part of the laws of war since their earliest incarnation. ${ }^{22}$ Motivated by religious dictates and codes of honor and chivalry, such rules regulated the payment of ransom in exchange for release of POWs, the duty to allow the enemy to collect its dead and bring them to burial, and so on.

First formally codified in the Lieber Code, rules on hors de combat were subsequently elaborated in the Hague Conventions of 1899 and 1907, the Geneva Conventions of 1949, and the Additional Protocols of 1977. These negotiated treaties included prohibitions on the denial of quarter (meaning, refusing to accept an offer to surrender), ${ }^{23}$ on harming those who have surrendered, ${ }^{24}$ and on mistreating POWs. ${ }^{25}$ The treaties further instructed that those who are wounded, sick, or shipwrecked be safeguarded from violence, treated humanely, and cared for. ${ }^{26}$

21 The Manual then proceeds to instruct that once a threat has been declared a hostile force, U.S. units and individual soldiers may engage without observing a hostile act or demonstration of hostile intent. The basis for engagement becomes status rather than conduct.

22 For a general history of the laws of war, see Stephen Neff (2005) \& Geoffrey Best (1983).

23 See Hague Regulations Art. 23(g); Protocol additional to the Geneva Conventions of 12 August 1949, and relating to the protection of victims of international armed conflicts (Protocol I) Art. 40, Jun. 10, 1977, 1125 U.N.T.S. 3 [hereinafter API].

24 Hague Regulations Art. 23(g); API Art. 41.

25 See Chapter II of the Hague Convention with Respect to the Laws and Customs of War on Land, Jul 29, 1899, 32 Stat. 1803 [hereinafter Hague Convention of 1899]; Chapter II of the Hague Convention of 1907, and Geneva Convention Relative to the Treatment of Prisoners, Aug. 12, 1949, 75 U.N.T.S. 135 [Geneva Convention III, hereinafter GCIII]. The Additional Protocol from 1977 expanded the entitlement to POW status but did not add much to the rights of POWs.

26 Geneva Convention for the Amelioration of the Condition of the Wounded and Sick in Armed Forces in the Field Art. 12, Aug. 12, 1949, 75 U.N.T.S. 31 [Geneva Convention I, hereinafter GCI]; Geneva Convention for the Amelioration of the Condition of the Wounded, Sick and Shipwrecked Members of the Armed Forces at Sea Art. 3, Aug. 12, 1949, 75 U.N.T.S. 85 [Geneva Convention II, hereinafter GCII]. 
The rules about hors de combat all share one underlying principle: Once soldiers are incapacitated — through surrender, capture, or injury—-they no longer pose a threat. As the ICRC commentary to the Geneva Convention explains, "it is only the soldier who is himself seeking to kill who may be killed. The abandonment of all aggressiveness should put an end to aggression" (Pictet 1952, 136). All soldiers who are not injured or captured are presumed to be "seeking to kill," and therefore the deliberate targeting of all enemy combatants - regardless of their role on the battlefield, whether they are off duty, asleep in the barracks, bathing in the lake, or retreatingis permissible. ${ }^{27}$ There is no duty to warn enemy combatants prior to an attack, to try to capture enemy combatants as POWs instead of killing them (a duty that existed under the medieval codes of knightly conduct in respect to other knights) (Stacey 1994, 30), to injure them instead of killing them, or in any other way minimize combatant casualties.

An interesting historical anomaly is the rule prohibiting shooting at aircrew parachuting in distress (as opposed to shooting at parachuting soldiers in deployment) (Pilloud et al. 1987, 495) ${ }^{28}$ This constraint was borne out of the early admiration of pilots: During World War I, "The adversary who had been brought down in flames was entitled, not to bullets, but to a salute as he went down, to wishes for his recovery if he were wounded, and flowers if he were dead" (Pilloud et al. 1987, 494). Although this provision could be understood as being akin to the protections accorded to shipwrecked seamen who were hors de combat, it was probably more inspired by notions of chivalry (aircraft being the new "steed," fit for gallant knights alone, and air-fights being the new "tournaments"), as the bailing aircrew were protected even when they parachuted back into their own territory and were able to resume their combat activity shortly thereafter (Pilloud et al. 1987, 494-496).

In sum, the exception of hors de combat is the only manner by which the class-based distinction is supplemented by a threat-based analysis. In the following sections, I argue that this threat-based analysis can and should be expanded beyond this exception.

27 See W. Hayes Parks (1989): “Combatants are liable to attack at any time or place, regardless of their activity when attacked... An individual combatant's vulnerability to lawful targeting (as opposed to assassination) is not dependent upon his or her military duties, or proximity to combat as such."

28 API Art. 42. Although the provision in API was a new one, several military manuals contained a similar provision. 


\subsection{Distinction}

Described as "cardinal" by the International Court of Justice, the principle 33 of distinction is the foundation of much of the current laws of war: "remove the 'principle of distinction' and the entire IHL system collapses" (Dinstein 2007, 146). Together with the principle of military necessity, it makes up the "deal" that IHL strikes between the need for war and for killing in war and the humanitarian concern for those affected by wars: It allows the sacrifice of combatants and military objects in exchange for sparing civilians and their property.

The exact scope of the principle of distinction has been the center of centuries' long religious, philosophical, and legal debate over Just War theory. In the fifth century, Augustine's justification for war as a just and even loving punishment for the wrongdoing of the enemy allowed the killing of all enemy nationals, civilians and combatants alike. The dependency of the justness of killing on the justness of war remained the predominant view throughout the following centuries (rearticulated by Averroes, Thomas Aquinas, and Francisco de Vitoria). ${ }^{29}$ It was only in the seventeenth century that Hugo Grotius, followed a century later by Emmerich de Vattel, and relying on a secular conception of natural law, insisted on separating the justness of the cause of war from the justness of the means of prosecuting the war. Accordingly, the fate of people could no longer depend on whether their country should be "punished," but instead on whether they played a role in fighting. This was not only a secular move, but also a strategic one; for once the knightly model of war was replaced with mass armies and mercenaries, the ability to ascribe "guilt" to individual soldiers, even those fighting unjust wars, was further diminished. Both these notions- the independence of the jus in bello from the jus ad bellum, and the sparing of all those who do not partake in hostilities - are at the foundation of modern laws of war.

The present-day principle of distinction, which is both customary and treaty-based, has two dimensions: One applies to people, the other-which requires a more fine-grained judgment in application-to objects.

\subsubsection{The Distinction Between Civilians and Combatants}

The human aspect of the principle of distinction is status-based: One is 36 either a "civilian" or a "combatant," with a set of distinct protections and

29 For the intellectual history of the notion of civilian immunity, see Colm McKeogh (2007). 
obligations that is attached to each. This seemingly neat division between the two categories, however, is subject to much debate.

IHL's definition of "civilians" is a residual one and comprises all those who do not fall under the category of combatants. ${ }^{30}$ In cases of doubt, an individual must be presumed to be a civilian. Civilians are not allowed to take part in hostilities, and in exchange for their nonparticipation, they are entitled to immunity from any deliberate attack (even if not from unintentional harm). Article 51(3) of Additional Protocol I, 1977 (“API") sums up this principle when it ensures immunity to civilians "unless and for such time as they take a direct part in hostilities." ${ }^{31}$ If a civilian takes a direct part in hostilities, he turns into a de facto combatant for purposes of targeting; but unlike the privileged combatant, he may also be tried and punished for the mere participation in the war effort. The exact scope of civilian immunity thus hinges upon the definition of "combatants" (civilians being defined in a residual manner) as well as on the interpretation of Article 51(3) (the conditions under which a civilian turns into a combatant).

The terms "combatants," "belligerents," and "members of the armed forces" are used interchangeably, while the term "soldier" is nowhere used or defined in the basic documents on the laws of war. Article 43(2) of API stipulates that "The armed forces of a Party to a conflict consist of all organized armed forces, groups and units which are under a command responsible to that Party for the conduct of its subordinates...." It then proceeds to stipulate that "Members of the armed forces of a Party to a conflict other than medical personnel and chaplains ... are combatants, that is to say, they have the right to participate directly in hostilities." The right to participate in hostilities means that, unlike civilians who take part in the fighting, combatants break no law by merely participating in combat, so long as they follow the laws of war. On the battlefield, they may kill enemy soldiers, with few limitations; if captured, they may not be tried or punished for doing so, unless they have also committed war crimes. They may only be subject to detention by enemy forces as POWs.

Hence, although in the ordinary meaning, "combatant" is a person who fights, in the legal sense, "combatant" is anyone who has a

30 API Art. 50.

31 API Art. 51(3). On the interpretation of Art. 51(3), see HCJ 769/02 The Public Committee Against Torture in Israel v. The Government of Israel [2005] (not yet published), available at: http://elyon1.court.gov.il/Files_ENG/02/690/007/A34/02007690.A34.pdf (Barak's opinion). 
right to fight under international law, and this right is accorded to all members of the armed forces, other than medical personnel and chaplains. Another exceptional category is soldiers assigned exclusively to civil defense tasks. ${ }^{32}$ All three-medics, chaplains, and civil defense forcesmust wear a distinctive emblem to identify them as such. Other than these categories, all soldiers are targetable unless they become hors de combat, and it is irrelevant if they are conscripted or volunteers, serving on the frontline or in the rear, engaging in combat, combat-support, or noncombat activities.

An earlier distinction between members of the armed forces who are combatants and those who are not, which appeared in Article 3 of the 1907 Hague Regulations, was considered and expressly rejected during the negotiations of the 1977 API. The ICRC's commentary on API states:

In fact, in any army there are numerous important categories of soldiers whose foremost or normal task has little to do with firing weapons. These include auxiliary services, administrative services, the military legal service and others. Whether they actually engage in firing weapons is not important. They are entitled to do so, which does not apply to either medical or religious personnel, despite their status as members of the armed forces, or to civilians, as they are not members of the armed forces. All members of the armed forces are combatants, and only members of the armed forces are combatants (Pilloud et al. 1987, 515).

The claim that "all members of the armed forces are combatants" is generally undisputed. There are heated debates, however, about the status of those who are not members of national armed forces, namely irregular forces. Without elaborating on its scope and background, the dispute is essentially over a question that is pivotal to the modern battlefield: Should nonstate paramilitary forces who do not distinguish themselves from the civilian population be considered lawful combatants, unlawful combatants, or else civilians who take part in hostilities? ${ }^{33}$ This controversy has reemerged with full force with the advent of the "war on terror," and the need to classify terrorists as either combatants (lawful or unlawful) or civilians for purposes

32 API Art. 61(a).

33 On the distinction between lawful and unlawful combatants generally, see Dinstein (2007, 150-156) and cf. Marco Sassòli (2006); Nathaniel Berman (2004). For the view that unlawful combatants are essentially civilians, see Michael Schmitt (2008). 
of targeting or detention. ${ }^{34}$ I return to the implications of this controversy later in the paper.

\subsubsection{The Distinction Between Civilian and Military Objects}

Article 52(1) of API expresses the obligation to distinguish in targeting between military and civilian objects. As in the case of human beings, the definition of civilian objects is residual and encompasses all nonmilitary objectives. Unlike the case of human beings, however, the definition of military targets is not one of status but of function. Article 52(2) of API states that "military objectives are limited to those objects which by their nature, location, purpose or use make an effective contribution to military action and whose total or partial destruction, capture or neutralization, in the circumstances ruling at the time, offers a definite military advantage." 35

There are thus striking differences between the rules on the permissible targeting of individuals and the permissible targeting of objects: Although any member of the armed forces is presumed to be contributing to military action so that his or her killing is presumed to gain a definite military advantage, objects must stand a case-by-case test of contribution and advantage to justify their destruction, capture, or neutralization. ${ }^{36}$ Specifically, the Protocol makes no distinction between "military objects" and dual-use objects, which would have followed the distinction between military personnel and civilians who may or may not serve military functions; instead, it treats all objects as potentially dual-use. Thus, a tank exhibited at the Smithsonian is not a legitimate target, but an exhibitionguide soldier is.

This difference in targeting standards might be justified on the account that there is often more time to assess the nature of an immovable target than the identity of moving human beings. But this is not always the case, nor does the Protocol limit the obligation to engage in case-by-case evaluations to instances where the assessment can be made at leisure.

34 On the debates surrounding the status of Al Qaeda or Taliban members, see generally Ryan Goodman (2009); Derek Jinks \& David Sloss (2004); Joseph Bialke (2004); Kenneth Anderson (2002).

35 Other specific provisions accord special protection to cultural objects and places of worship (Art. 53), objects indispensable to the survival of the civilian population (Art. 54), the natural environment (Art. 55), or works and installations containing dangerous forces (Art. 56).

36 For an elaborate and illuminating analysis of legitimate military objectives, see Parks (2007). 


\subsection{Proportionality}

The principle of proportionality signifies the distinction between the deliberate killing of civilians (or attacking civilian objects), which is always prohibited, and the realization that no war can be fought without inadvertently affecting the innocent. Following the Catholic doctrine of double effect, which distinguishes between intended and foreseen consequences, it allows for the foreseen-yet-unintended killing of civilians (or damage to civilian objects), provided that such "collateral harm" is not excessive in relation to the overall military advantage that is to be gained from the attack. The principle of proportionality further mandates that combatants take all feasible precautions to minimize collateral harm that might result from their military actions.

The principle of proportionality in jus in bello has never been interpreted, nor does its language suggest that it should be interpreted, as applying to enemy combatants. There is thus no duty to minimize harm to enemy combatants. The Rome Statute of the International Criminal Law, which lists all indictable war crimes, makes no reference to an excessive killing of combatants. ${ }^{37}$ In fact, the killing of more enemy combatants has been generally understood as a central component of "military advantage," against which harm to civilians must be measured.

Some commentators have linked the excessive killing of combatants in war to the necessity and proportionality requirements of the just use of force under the jus ad bellum prong of the laws of war. There are debates in the literature on whether the necessity and proportionality requirements of the jus ad bellum apply to any act in war or govern only the initial use of force, or in other words, whether they apply tactically, strategically, or even politically. ${ }^{38}$ It is unnecessary here to chime in on this debate; for even to those advocating the law's most expansive reading, these requirements have not been read as prohibiting the killing of all enemy combatants in the course of legitimate military operations under the jus in bello. Nor do military manuals seem to support such a reading in instructing their troops on the laws of war.

\subsection{A Note on International Human Rights Law}

There has been a noticeable effort among human rights activists to complement and interpret IHL norms with or in light of the more expansive

37 See Rome Statute of the International Criminal Court Art. 8, Jul. 17, 1998, 2187 U.N.T.S. 90.

38 Cf. Christopher Greenwood (2000) (arguing that the jus ad bellum requirements must be kept separate from the jus in bello) with Paul Christopher (2004). 
and protective norms of international human rights law (IHRL). This humanitarian drive has been promoted, in part, by the existence of judicial institutions, such as the European Court of Human Rights, which have jurisdiction over IHRL claims but not IHL ones. ${ }^{39} \mathrm{~A}$ recent context in which this effort has been particularly evident is the "war on terror" and the debates over the standards that should apply to the targeting and treatment of terrorists. ${ }^{40}$

And still, the human rights community, advocates and scholars alike, has remained fairly silent in discussions of the right to life of a country's own military forces (discussions that have taken place among political theorists). ${ }^{41}$ Particularly, it has failed to advance principled claims about the obligations owed by the government to its own soldiers or comment on the legitimacy of the interstate consensus around the sacrifice by governments of some portion of their domestic population (for example, soldiers) for the benefit of the rest (for example, civilians).

True, governments try to protect their soldiers, partly by employing more aggressive force toward the enemy (including by "risk-transfer" from soldiers onto enemy forces and civilians). But the terms of engagement, as far as the soldiers are concerned, are that death on the battlefield is not only an occupational hazard, but also something the government has agreed to in advance as lawful and legitimate. This makes soldiers' terms of engagement conceptually different from the occupational hazards of police officers, fire fighters, or any other public servant: Not only do they undertake risk, in effect, they are expected to forfeit their right to life (Kasher 2009a, 10).

\section{SOLDIERS-THE VIEW FROM PHILOSOPHY}

Philosophers have paid far more attention to combatant targetability than their colleagues in the legal profession have. And even though the present-day

39 See, e.g., Isayeva v. Russia, App. No. 57950/00, 41 Eur. H. R. Rep. 847 (2005) (applying right-tolife analysis to Russian military strikes in Chechnya); Ergi v. Turkey, 1998-IV Eur. Ct. H.R. 1751 (applying a similar analysis to a clash between Turkish forces and members of the Workers Party of Kurdistan). Note, however, that in these cases, the state in question itself denied that the context was one of an armed conflict, thus denying the application of IHL altogether. For a discussion of these cases, see William Abresch (2005).

40 See generally Anderson (2007) and Natasha Balendra (2008).

41 See, e.g., Thomas Hill Green (1895). 
philosophical literature that offers justifications for killing in war might still be preoccupied mainly with the non-killing of noncombatants (with some notable exceptions that I reference later), it is within this scholarship that some doubts concerning the legitimate scope of targeting combatantsdoubts that are largely absent from legal scholarship—are voiced.

Three strands of modern justifications for killing in war stand out, and I group them roughly in three categories: immunity theory, honor theory, and convention. I note those criticizing these justifications as well as those questioning their implications with regard to the permissible killing of soldiers. These critiques are later used in Part 5 of the paper to support my own normative argument.

\subsection{Immunity Theory}

The most common strand of justification for killing in war largely relies on the paradigm of self-defense and is forwarded by those who have been dubbed "immunity theorists." ${ }^{2}$ Early versions of the immunity theory hark back to earlier versions of Just War theory and the coupling of the just cause of war with its just prosecution. For Elizabeth Anscombe (1970), combatants are targetable when they pose a threat and are engaged in "an objectively unjust proceeding." Some contemporary writers, such as Jeff McMahan (2006), Paul Ramsey (1968), and Robert Holmes (1989) ${ }^{43}$ follow in Anscombe's footsteps and reject the principle of the "moral equality" of soldiers by which the status of combatants fighting just wars is equal to those fighting on behalf of unjust aggressors.

An obvious problem with this position-one that first drove Grotius in the seventeenth century to argue for a separation of the jus ad bellum from the jus in bello-is the lack of arbitrator to determine which wars are just and which are not. Almost all parties who engage in war believe they are fighting for just causes; if the justice of the cause cannot be easily determined, there could be no practical benefit from a system that purports to impose limitations on the "unjust" party alone. Another difficulty is the assumption of collective guilt on the part of all soldiers or the collective innocence of all civilians and the inevitable realization that some civilians (e.g., the informed farmer who supports Nazi propaganda) would always

42 The term was offered by George Mavrodes (1975) and then followed by others, such as Robert Fullinwider (1975).

43 See also Daniel Zupan (2004). 
be more morally culpable than some of their naïve and uneducated compatriot soldiers (Mavrodes 1975, 81).

It is for this reason that most contemporary immunity theorists, such as Thomas Nagel (1972) or Fullinwider (1975), follow present-day IHL and reject notions of morality and guilt as a basis for determining targetability. They juxtapose "innocence" not with "guilt," but with "threat" or "danger," and justify the targeting of soldiers under the principle of self-defense. Being innocent (that is, unthreatening), the civilian is immune from attack, while the dangerous soldier is susceptible to it. ${ }^{44}$

But even if "innocence" is juxtaposed with "danger," and not with "guilt," the collective determination that all civilians are unthreatening and all soldiers are threatening is an uneasy one. Questioning the scope of civilian immunity that could be justified on the basis of the self-defense paradigm, Lawrence Alexander $(1976,415)$ concludes that "the intentional killing of innocent noncombatants is not necessarily immoral ... [because] the right to kill in self-defense requires only that the person killed be a necessary or sufficient cause of a danger, not that he be morally guilty.” C. A. J. Coady (2008, 154) expands the groups of civilians who might be targeted on the basis of "threat" to include "the political leadership of an unjust war, civilian scientists developing weapon systems for that enterprise, civilian conspirators who have successfully plotted to bring about the war for their own purposes, and so on," acknowledging that his stance allows the targeting of more civilians than the laws of war currently allow. And Michael Green $(1992,43)$ goes even further to argue that civilian innocence is a relic of the past, when "the people had no part to play in legitimizing, commanding, or controlling the activities of the government." Such is not the case today, because "war became a conflict among nations and peoples involving the total mobilization of those nations" (Green 1992, 43). His assertions are especially resounding if one considers the claim that democratic accountability improves the war performance of the country. ${ }^{45}$ Although emphasizing the growing responsibility of the civilians in society, Green stops short of challenging the corresponding assumption about the "threat" or "culpability" of all combatants.

44 See Fullinwider (1975), explaining that "the distinction between combatants and noncombatants derives from the operation of the Principle of Self-Defense. Our obligation not to kill noncombatants stems from our obligation not to kill without justification; and the Principle of Self-Defense justifies killing only combatants." For a similar argument, see also John Ford (1970).

45 See Samuel Issacharoff (2009). 
Some accounts for why all soldiers should be considered threatening are offered by other immunity theorists, who rely on the collective nature of war and on the role of soldiers as agents of their country. Walzer ([1977] 2006,138 ) argues that war cannot be fought without discriminating between fighters and nonfighters, where the former "are subject to attack at any time." 46 The reason for this, he claims, is that the soldier has allowed himself "to be made into a dangerous man" (Walzer [1977] 2006, 145). Acknowledging that not every soldier is dangerous at every time, and that simple soldiers are not necessarily "responsible" for their government's actions, ${ }^{47}$ he believes the class of soldiers is dangerous, and this fact is what distinguishes any individual soldier from all civilians. Noam Zohar further develops this notion to create what he terms "extended self defense," which accounts for the killing of soldiers who are neither directly responsible for their government's actions nor threatening at a particular moment: "War is perceived and described properly only when we see it as being waged between nations rather than simply between two hosts of individual soldiers.... Civilians too are members of the nation, but their identity as individuals is paramount whereas those who wear the national uniform are rightly identified as embodying the nation's agency" (Zohar 2004, 739).

This class-oriented variation of immunity theory thus allows for a uniform treatment of all soldiers, regardless of their immediate role, function, or the degree of threat they pose. They are denied any individual identity, and are instead considered all to be members of a group, which the state sends to kill and be killed on its behalf, so that a larger group-namely, civilians_can be protected.

The obvious problem with the class-based theory is its circularity: We designate soldiers as agents of the state, and once designated as such, they are targetable. But why should only soldiers be agents of the state? Why

46 See also Coady (2004) and Noam Zohar (1993, 615), who emphasizes that killing in war cannot be justified by direct analogy to self-defense on the private level: "Where the basic analogy to self-defense does function is on the collective level, justifying self-defensive war itself despite its necessary cost in innocent lives"; and Uwe Steinhoff $(2007,54)$, who argues that it is not so much the actual non-innocence or innocence of any individual target as much as it is what the attacker can know with some degree of certainty about the individual that should underlie the distinction doctrine. In this, Steinhoff's emphasis seems to be on the administrability of the moral rule more than on its application in each particular case.

47 Walzer ([1977] 2006, 28) does distinguish between conscripted soldiers and volunteers. He describes his disagreement with Thomas Hill Green (1895) over his own proposition that "no wrong is done in war if 'the persons killed are voluntary combatants."' As he notes, Green questions the degree to which soldiers actually volunteer to go to battle, as opposed to serving a state action. 
should all soldiers be agents of the state? Taken to extreme, why should the class theory not revert back to Augustine's punitive model of the fifth century that collapsed any distinction between the king and his subjects? These questions are especially pertinent as most class theorists also share a strong commitment to democracy. One could easily make an argument, as Michael Green $(1992,43)$ does, that voting (and perhaps nonvoting) citizens in a democracy should be considered as responsible as any soldier for their government's actions. ${ }^{48}$

Immunity discussions at times express some uneasiness about the targeting of all enemy combatants under all circumstances. Alexander (1976, 413) emphasizes that some combatants might be less dangerous and contribute less immediately to the war effort than their civilian compatriots. ${ }^{49}$ Thomas Nagel $(1972,140)$ is willing to admit that not all those in uniform are necessarily threatening. And Coady $(2008,164)$ concludes that "there should be a presumption that warriors are entitled to direct lethal force against opposing warriors where they have some plausible warrant for seeing them as wrongdoers or attackers ... the presumption is much weaker, even rebuttable, in cases where the enemy troops are palpably in the right, or offer no serious threat." ${ }^{\prime 50}$ None of these discussions, however, elaborates on the limitations pertaining to the killing of enemy combatants or on their practical implications, at times merely noting that such limitations would be "an indictment of widely accepted norms of warfare" (Alexander 1976, 413).

48 Green $(1992,43)$ writes, "In a perfect democracy each and every person would be ... fully responsible, because if the method of consent has been in operation, each has agreed to the decision reached by that method, or, if not that, to be bound by whatever decision was reached by that method." A similar argument has been advanced by Igor Primoratz (2002).

49 Alexander's conclusion, nonetheless, focuses on expanding the permissible targeting of civilians without a corollary contraction of the permissible targeting of combatants.

50 Earlier in his chapter, Coady $(2008,157)$ adds: "there are wrong ways to treat enemy troops, some of which are covered by the proportionality requirement of the JIB [jus in bellum - G.B.]. When we know that enemy troops are demoralized and ready to surrender, then further prosecution of lethal attacks upon them is surely showing disrespect for human life and for the humanity in them specifically, your entitlement to injure and kill them is restricted by its necessity for furthering the war aims that are legitimated by your just cause, and when attacks upon them are no longer required by those aims, then the normal respect for human life should resume and be exhibited in your conduct." It is unclear whether the just cause is the determining factor in weighing the legitimacy of the decision to continue to fight, or the state of the enemy troops. In any case, Coady's claim that this issue is covered by the "proportionality requirement of the JIB" is inaccurate. 


\subsection{Honor Theory}

Another strand of justification for noncombatant immunity (and thus, by extension, for combatant targetability) relies on medieval notions of honor and dignity. Nagel $(1972,134)$ employs the distinction between "fighting fair" and "fighting dirty" to explain why killing enemy combatants is compatible with treating them as human beings, whereas killing civilians is not. Henry Shue $(1978,129)$ has argued that preserving the principle of noncombatant immunity "allows for a 'fair fight' by means of protecting the utterly defenseless from assault." Under the honor theory, civilian immunity is not a matter of innocence from either moral culpability or threat, but instead of the ability to participate in a fair and honorable fight. Present-day reliance on notions of honor is reminiscent of Thomas Hobbes's rejection of unnecessary violence or cruelty in war: "though there be in war no law, the breach whereof is injury, yet there are those laws, the breach whereof is dishonour. In one word, therefore, the only law of actions in war is honour; and the right of war providence" (Hobbes [1640] 1999, 104). Why it should be honorable to kill all soldiers, regardless of their role or their actual ability to participate in a "fair fight," however, remains unanswered.

Paul Kahn's $(2002,1999)$ ideal of fair fighting is more nuanced, prohibiting not only the killing of civilians, but also the killing of combatants who are substantially inferior in power. For Kahn $(2002,3)$, addressing asymmetrical warfare, the right of combatants to kill one another depends on some rough notions of equality of power, as a reciprocal claim of selfdefense can exist only "as long as they stand in a relationship of mutual risk." Asymmetric war is "an image of warfare without the possibility of chivalry" (Kahn 2002, 4). Without mutual risk, war is not war anymore, but a policing action; "The moral condition of policing, however, is that only the morally guilty should suffer physical injury. There might be exceptions to this rule, but there is no wholesale license to target the morally innocent" (Kahn 2002, 4). Kahn, however, does not extend his argument to all theaters of war; in essence, his challenge is not so much of the right to kill soldiers in war, but of labeling asymmetrical conflicts as "wars" in the first place.

\subsection{Convention}

A third strand of theory denies any moral content to the principle of distinction and views it, instead, as a mere convention that states have agreed upon in regulating their warfare. The preeminent advocate of this theory, George Mavrodes (1975), argues that this convention is intended to limit the 
destructive effects of wars in some readily applicable way, but cannot be justified on any inherently moral grounds, any more than a convention about driving on either the left- or right-hand side of the road can be. ${ }^{51}$ For Mavrodes, the sacrifice of soldiers for the benefit of civilians is essentially an extension of the dueling idea: If we could resolve all conflicts by a single duel, fought by one volunteer from each side, then that would undoubtedly be the best compromise between the ideal of pacifism and the resigned acceptance of the necessity of war. But because the single duel is a utopia unlikely to be accepted by warring rivals, a different convention-one of armies fighting one another-has been adopted. Mavrodes is ready to concede that if an alternative convention, one capable of further reducing the harmful effects of war, is adopted, then there is no essential moral superiority to the current one.

Mavrodes's arguments can be formulated in the following manner: The principle of distinction is useful only to the degree it approximates, in the best possible way, the values we want to promote in regulating warfare, namely recognizing the need to allow parties to prosecute wars, including by killing some individuals, while protecting to the extent possible other individuals.

\subsection{Critiques}

But does the current status-based principle best approximate these values? At least two philosophers argue that it does not. The first is Larry May, who accepts the general self-defense paradigm but objects to its rigid statusbased application, not only as it pertains to civilian immunity but also as applied to combatant targetability.

Like others before him, May (2007) begins by rejecting the application of a simplistic distinction between combatants and civilians on the basis of the threat they pose ("most soldiers never fire a shot"). Consequently, it becomes questionable to what degree status-based or class-based distinctions between "combatants" and "civilians" are useful in informing targeting decisions:

What is at stake here is whether social group categories should be used as absolute rules that are in themselves sufficient for action decisions, or whether the group categories are merely guides that inform but do not determine our actions (May 2007, 115).

The stakes are heightened when one embraces, as May does, considerations of humanity and human compassion, even where the lives of one's enemies 
are concerned. These considerations dictate that the permissible killing of combatants in war is merely a rebuttable presumption, which must be tested on a case-by-case basis. In any particular case, testing the presumption requires a real consideration of the value of human life, so that intentional killing is only justified by the threat emanating from the individual target under the prevailing circumstances. The just or unjust cause that combatants fight for is irrelevant in May's analysis, which thus ensures the integrity of the jus in bello as independent from the jus ad bellum.

May's ally in challenging the status-based distinction is Israeli philosopher Asa Kasher, who attacks the existing principle of distinction as violative of soldiers' human dignity. Kasher emphasizes the value of all human life, including that of enemy combatants, and finds that the license to kill all enemy combatants without further justification other than a presumption of dangerousness pays insufficient heed to this value. In consideration of the lives of a state's own soldiers, he advances an argument about the state's obligations to its own citizens - civilians and soldiers - thereby questioning the normative acceptability of an interstate agreement that permits the killing of all soldiers (Kasher 2009b, 55-86). Like May, he ultimately demands finer-grained distinctions that would spare the unthreatening combatant (Kasher 2009a).

For both philosophers, the move away from status-based distinctions to individual-based determination has the simultaneous effect of sparing more soldiers and endangering more civilians. The naked soldier, who under existing IHL is a legitimate target, is saved, while the munitions factory owner, who is currently probably immune from deliberate attack, loses that immunity.

In the following sections of this paper, I join the critics and explain why the current understandings of the principle of distinction, as well as of the principle of military necessity, no longer serve as best approximates of the values that IHL seeks to promote. Following the moral intuitions of those who challenge the status-based orientation of the targeting doctrines, I work within the existing legal frameworks to show how the status test should be complemented by a functional test. I employ a positive analysis of the changing nature of wars and warfare to make a normative argument about the effects these changes should have on the reading of the laws of war. My attempt is to show that even without demanding that warring parties demonstrate compassion toward each other, there are reasons to question whether modern warfare still warrants an interpretation of the principle of military necessity as justifying the killing of as many combatants as possible. 


\section{SOLDIERS-THE VIEW FROM THE BATTLEFIELD}

The laws of war have always been a creature of their time, shaping and evolving in correspondence to geopolitical developments, technological innovation, and changing social and cultural preferences. ${ }^{52}$

It is beyond the boundaries of this present work to elaborate at great length on the historical evolution of the changing nature of wars since the nineteenth century and the early formulations of the principle of military necessity in jus in bello. However, certain crucial differences in how wars are fought and won are relatively straightforward and obvious, notwithstanding the many similarities that persist.

Of these differences, three major developments can be identified: The first is a declining importance of the "generic combatant," which calls into question the understanding of "military necessity" as justifying killing as many enemy soldiers as possible. The second is a growing civilianization of the armed forces, which calls into question the rationale and applicability of the traditional principle of distinction. And third is the development of new technologies that allow for greater discrimination in targeting, which suggests the possibility of revising the existing targeting doctrines in ways that would require more fine-grained distinctions.

\subsection{The Declining Importance of the "Generic Combatant"}

Ancient, medieval, and early modern wars were fought over territory and domination. To conquer a territory and control it effectively, the military was essential. And to defend territory, harming as many enemy soldiers as possible was the most effective strategy. Modern wars may be still fought over territory and domination even though the acquisition of territory through war is outlawed, but combatants play a declining role in winning them. Military power, itself, is diminishing in its decisive ability to determine the fate of disputes. As one expert put it, "tactical supremacy alone is unlikely to achieve national strategic objectives except in the most particularized of cases" (Cunningham 2008, 116). In fact, a decisive victory can no longer be achieved through total submission of the enemy, in terms of its capacity to fight or threaten. In this reality, economic power, access to resources, infrastructure, international alliances and institutions, and domestic and international

52 For the effects of the changes in political structures, economy, and technology on the laws of war, see the various contribution in Michael Howard, George Andreopoulos, \& Mark Shulman, eds. (1994) and Philip Bobbitt (2002). 
public opinion have become as, if not more, crucial to national strategic goals generally and the war effort particularly (Smith 2005). This is especially true in nontraditional military-to-military international armed conflicts, where the ability of military power alone to bring about victory is even more doubtful than in the traditional conflicts (Kaldor 2006). See the American defeat in Vietnam, France's in Algeria, Israel's in Lebanon, the Soviets' in Afghanistan, or the survival of Al Qaeda or the Ugandan Lord's Resistance Army.

This point should not be overstated. I do not mean to suggest that military power is inconsequential in determining the outcome of wars, nor that economic power or access to resources were unimportant two hundred or two thousand years ago. The claim I make is much more modest, but important nonetheless. Of the entire set of factors that contribute to "victory," the weight of military power is declining in comparison with previous eras.

The second reason for the declining importance of combatants is the progress of technology on the battlefield (and I return to other implications of this development later in the article). In advanced militaries, there is no "generic" soldier; instead, soldiers contribute in vastly different proportions to the war effort: Some fly airplanes or command tanks, while others serve in laundry facilities - killing "as many as possible" is less important than disabling the more dangerous ones. Again, although there was clear differentiation in roles and importance between the infantry, cavalry, artillery, or the Marins of Napoleon's Grande Armée, and between all of those and support units, killing as many of the enemy's soldiers in the Napoleonic era would have increased one's chances of victory by an overwhelming margin (which might explain the 3.5-6.5 million military casualties of the Napoleonic wars) (Elting 1988; Fremont-Barnes \& Fisher 2004). Today, this margin is much smaller. ${ }^{53}$

Consider, for instance, long-term sieges on cities and states that in past times were intended to cut off the inhabitants from any supply that would help them maintain their resistance. Such sieges required the deployment

53 See also Michael Schmitt (2008, 24-25): "With forces facing each other across a FEBA (forward edge of the battle area), the immediate objective of warfare was to weaken the enemy sufficiently to allow one's own forces to seize territory. You wore the enemy down through attrition warfare, the serial destruction of its military... . Today, battlefields are multi-dimensional, i.e., technology has evolved to the point where the concept of a line marking the heart of the battle (with combat fading the greater the distance from that line) no longer makes sense. There may be ground forces facing each other, but the conflict is everywhere. Consider Operation Iraqi Freedom (OIF).... Indeed, the first blow of the war was not the crossing of the Iraqi border by an invasion force, but rather an attack by Tomahawk cruise missiles and F-117s designed to kill Saddam Hussein.” 
of mass armies to enforce them. But today, they can be replaced by control from the air or the sea, or by cyber attacks on economic and utilities infrastructure, of the kind employed by Russia to dismantle the Georgian banking and utilities systems during their 2008 war (Sanger, Markoff, \& Shanker 2009, A1). It is hardly surprising that the U.S. military now identifies cyber warfare as a major threat to national security. ${ }^{54}$ For these types of action, as well as to defend against them, a mass army is not useful or necessary, and consequently, nor is the killing of as many enemy soldiers as possible.

Sheer numbers of enemy casualties might nonetheless have an indirect contribution to the war effort in terms of garnering and maintaining domestic support. Recent decades have seen the birth and growth of an international "humanitarian conscience" (or "universal benevolence"), which comprises various trends, including a growing general aversion to war, a lower tolerance for civilian casualties (Gat 2009, Rogers 2000), ${ }^{55}$ and an increased care for the well-being of others, including enemy nationals. But this trend, to the extent it exists, does not include, as of yet, a general aversion to enemy combatant casualties. In fact, in 2004, U.S. military spokespersons began reporting the number of enemy deaths in Iraq (a practice that had been abandoned after Vietnam) in an effort to "frame" the casualties of coalition forces. The intuition was that the Western public would perceive the war effort more positively if the ratio of coalition deaths to enemy deaths was low; a controlled study subsequently confirmed this intuition (Boettcher \& Cobb 2006).

The effects of killing enemy combatants on garnering domestic support for the war or weakening the morale of the enemy might suggest that killing as many enemy soldiers as possible is in fact still necessary. But the term "necessary" here is probably closer to "convenient" or "beneficial" than it is to "crucial" or "vital." If generic enemy combatants are less useful as a war machine, killing them is less necessary to win the war. It might be "necessary" only indirectly, to garner domestic support or diminish the enemy's morale. Whether we allow the killing of people because it has a positive effect on domestic support or a negative effect on the enemy's morale is ultimately

54 As the U.S. general in charge of network warfare put it, "Maintaining freedom of action in cyberspace in the 21st Century is as inherent to U.S. interests as freedom of the seas was in the 19th Century, and access to air and space in the 20th Century" (Keith Alexander 2009).

55 Naturally, civilian casualties are more tolerated where there is a perception that national interests are at stake. Of course, there are those who claim that this humanitarian conscience is detrimental as well as dangerous to the U.S. (and Western) interests. See, e.g., Robert Mandel (2006). 
a normative judgment. The laws of war certainly ban other practices that might have had a negative effect on the enemy's morale (such as torture of POWs, the killing of civilians, the use of chemical weapons, and so on).

Moreover, the correlation between killing enemy combatants and greater domestic support or diminishing enemy morale is, in itself, a product of how we construct the battlefield. Because we allow the killing of as many enemy combatants as possible, and only as many combatants as possible, the measurement of (lawful) success is tied to the number of combatants killed. One could imagine, however, that under a different normative construction of the rules, one that would limit the lawful killing of combatants to that which is directly "necessary," the excessive killing of combatants would be tantamount to other practices that are banned under the laws of war, which might only outrage the enemy and domestic audiences to weaken the attacking forces. Domestic support, particularly, is tied to its perception of lawful and unlawful behavior, a fact evident from negative popular domestic sentiments about civilian casualties on the enemy's side.

To sum up this part, if the role of military power alone in determining political outcomes is indeed declining, and the degree of contribution to the military power by some individual combatants is minuscule, then the formulation of the principle of "military necessity" as allowing belligerent parties to "disable the greatest possible number of men" ${ }^{56}$ might be less apt today than in the St. Petersburg Declaration days. A much narrower formulation-one that only allows killing that is clearly necessary to achieve the war's aims - is in order. If so, the ICRC's submission that "in classic largescale confrontations between well-equipped and organized armed forces or groups, the principles of military necessity and of humanity are unlikely to restrict the use of force against legitimate military targets beyond what is already required by specific provisions of IHL" is a correct assertion of the law but unwarranted as a normative matter (Melzer 2009, 80).

Moreover, and perhaps more disturbing from a humanitarian perspective, many civilian functions - political, financial, infrastructure-have become more central to the war effort than military functions; maintaining the fiction of a status-based distinction between combatants and civilians becomes increasingly difficult to justify on any functional basis. This point is reinforced by the development discussed next. 


\subsection{Civilianization of the Armed Forces}

The changing nature of wars has been accompanied by a change in the nature of the armed forces fighting them, and in particular, the greater intertwining of combatants and civilians. Although this point has often been made with regard to insurgents or other nonstate forces, it is no less true for modern standing armies as well. This development poses obvious challenges to the principle of distinction, both conceptually and practically.

Armed forces were always dependent on civilians for their function. Civilians ran the politics, drove the economy, and provided the support needed for the armed forces to function. It is largely for this reason, practical rather than ethical, that in ancient times, by and large, peasants and civilian property were kept alive, as conquerors knew they were dependent on the crops and labor that civilians produced once the war was over. This is not to say that cases of wholesale slaughter and acts of wanton cruelty did not occur-only that they were not the rule.

The limited necessity of killing civilians helped define and maintain a principle of distinction from the beginning. It allowed war to be constructed as a phenomenon of combat between soldiers, who were distinguishable from civilians. Once war was established that way and accepted in such form by the pool of potential adversaries, the need to target civilians further diminished. Military necessity and distinction were thus two facets of the way sovereigns designed the battlefield.

Over the past several decades, however, the process of civilianizing the army has become more and more pronounced. The change is not merely a matter of degree: It involves blurring the geographical lines of front and rear, reshuffling roles and functions, and reallocating risk. It is in part for this reason (in addition to sheer cruelty or revenge) that the ratio of civilian to combatant deaths has been on the rise since the beginning of the twentieth century.

The civilianization of the American military has been a growing trend in recent conflicts. In Vietnam, the ratio between civilian contractors and uniformed military personnel was 1:5; in Desert Storm, it plunged to 1:100; but in Bosnia, it rose to 1:1. In Iraq today, the ratio is 1:1, and at some points in time, it was even higher on the contractors' side (Grier 2008; Manero $2007,5)$. The greater reliance on civilians is driven by considerations of efficiency (over the long run, the costs of contractors are lower than of employing soldiers (U.S. Congressional Budget Office 2008)) as well as a wish to decrease the public uneasiness about the number of troops deployed to 
war zones (on the assumption that the public is more sensitive to casualties among the armed forces than among contractors) (Avant \& Sigelman 2008, 34-37).

Within the U.S. military, a growing number of military positions are now performed by civilians employed by the military, including billeting, logistical support, meteorological monitoring, and healthcare. Civilian contractors in Afghanistan and Iraq increasingly perform a variety of roles that had traditionally been thought of as exclusively military, including security detail, prisoners watch, and weapons systems analysis. Outside a few exceptions, it has become virtually impossible to guess who performs which tasks: The Army Corps of Engineers is building bridges in Afghanistan, while civilian contractors are in charge of the engineers' security. ${ }^{57}$ And, as one military officer observed, "[g]iven the current operational environment, military support personnel and their civilian counterparts are as vulnerable, if not more so, to attacks than combat units on patrol" (Lindemann 2007, 84). These developments have posed increasing challenges for the principle of distinction, both practically and conceptually: The degree of military threat that an individual poses no longer correlates with whether she is in uniform or not. In fact, militaries could choose to outsource all noncombat operations to civilian contractors, just as they could choose to outsource combat operations to civilian contractors (notwithstanding the question of how these contractors would be treated if captured on the battlefield).

Alongside the civilianization of the standing militaries of western countries, the role of nonstate actors as participants on the battlefield has increased dramatically. Among these actors, the blurring lines between civilians and combatants are even more structural, given the integration with and reliance on the civilian population by the insurgents. This integration is in part a result of and reaction to the IHL principle of distinction. By according civilians greater protection on the battlefield, the principle encourages the insurgents to assume the posture of civilians (a moral hazard problem). Moreover, distinguishing among individuals as either combatants or civilians is a difficult task when it comes to nonstate actors, not only because the latter generally do not wear uniforms or maintain distinctive emblems, but because functionally, insurgents are often combatants only

57 See, for example, a government solicitation of contractors to perform security operations for the Army Corps of Engineers in Afghanistan, available at https://www.fbo.gov/ index? $\mathrm{s}=$ opportunity\&mode $=$ form \&tab $=$ core\&id $=a 4 f b f e 10 d 60 a f 9 c 7 b 7378 b 3062 \mathrm{e} 3 \mathrm{~b} 5 \mathrm{ab} \&$ _ $\mathrm{cview}=1 \& \mathrm{cck}=1 \& \mathrm{au}=\& \mathrm{ck}$. 
"part time." In addition, political leadership and military commanders are more closely intertwined in nonstate groups than in national structures, not only in purely military factions, such as Al Qaeda, but also in armed groups with national political aspirations such as Hezbollah, Hamas, or the former IRA.

All of these have posed a significant challenge for countries fighting insurgents, terrorists, or other nonstate actors. Naturally, the civilianization of national militaries poses similar problems for the principle of distinction, even if the trend is driven by other considerations; indeed, it is somewhat ironic that countries' efforts to expand the exceptions to civilian immunity in the context of counterinsurgency take place just as these countries expand their own militaries' reliance on civilians. For present purposes, however, I want to focus on the recent debates surrounding the targeting and detention of nonstate actors, particularly terrorists, because they demonstrate an important shift in the application of the principle of distinction. They also offer a better case study for the current application of the principle of distinction, because as a generalization, militaries (particularly, western militaries) exhibit greater commitment to follow the principle of distinction than insurgents or terrorists do.

Terrorists are classified as either combatants (lawful or unlawful) or as civilians who are taking direct part in hostilities. ${ }^{58}$ On the traditional battlefield, this distinction would have made a great difference for purposes of permissible targeting, because combatants might be targeted at any time, in any place, for any role they play, while civilians might only be targeted "for such time" that they take a "direct" part in hostilities. As applied to the context of the "war on terrorism," however, this distinction proved to be much less significant, because it was replaced, instead, by a functional test of "threat" or "guilt" (with the distinction between "threat" and "guilt" not being consistently preserved).

In 2005, the Israeli High Court of Justice (HCJ), when reviewing the government's policy of targeted killings of terrorists in Gaza and the West Bank, classified terrorists as civilians taking direct part in hostilities. ${ }^{59}$ It ordered that terrorists be targeted only when there was sufficient intelligence

58 See supra notes 33-34.

59 HCJ 769/02 The Public Committee Against Torture in Israel v. The Government of Israel [2005] (not yet published), available at: http://elyon1.court.gov.il/Files_ENG/02/690/007/ A34/02007690.A34.pdf. 
to show that the individual targeted was directly, substantially, and continuously involved in terrorism - a standard that would have been unnecessary had members of paramilitary groups been labeled "combatants." Still, when interpreting the limitation "for such time," the HCJ rejected the possibility of a "revolving door" allowing a terrorist to act as a terrorist by day and a civilian by night, substantially weakening the temporal constraint. In effect, the Court allowed the government to target terrorists any time, any place, as long as the "guilt" of the terrorist has been established. In other words, the functional test of the nature of the target made the distinction in labeling the individual a "civilian" or a "combatant" less meaningful.

Unlike its Israeli counterpart, the American Supreme Court was ready to accept the U.S. government's position that terrorists should be classified as combatants, specifically unlawful combatants. ${ }^{60}$ The question of when and how terrorists might be targeted has never been addressed. But from the discussions of their permissible detention, a similar functionality test can be noticed.

In March 2009, the U.S. government stated its position on the detention of terrorists in its submission in the Re Guantanamo case. ${ }^{61}$ The submission argues for an expansion of the criteria for detaining suspected terrorists beyond members of Al Qaeda or the Taliban, to include "associated forces that are engaged in hostilities against the United States or its coalition partners, including any person who has committed a belligerent act, or has directly supported hostilities, in aid of such enemy armed forces." 62 In determining who "directly supported hostilities," the submission proceeds to argue:

It is neither possible nor advisable, however, to attempt to identify, in the abstract, the precise nature and degree of "substantial support," or the precise characteristics of "associated forces," that are or would be sufficient to bring persons and organizations within the foregoing framework.... Accordingly, the contours of the "substantial support" and "associated forces" bases of detention will need to be further developed in their application to concrete facts in individual cases. ${ }^{63}$

60 Hamdi v. Rumsfeld, 542 U.S. 507, 518 (2004) (relying on Ex parte Quirin, 317 U.S. 28, 30 (1942)).

61 Resp'ts' Mem. (Misc. No. 08-442), In Re: Guantanamo Bay Detainee Litigation, D.D.C., available at http://www.usdoj.gov/opa/documents/memo-re-det-auth.pdf.

62 Id. at 2.

63 Id. 
Although the submission was careful to limit itself to the question of detention, the case-by-case assessment of the conduct of particular individuals might carry important implications for targeting as well.

Moreover, the American counterinsurgency doctrine orders commanders to distinguish between "reconcilable" and "irreconcilable" insurgents for targeting purposes, so that even among those who are prima facie targetable, those who might be susceptible for reconciliation are to be spared: "We must strive to make reconcilables a part of the solution, even as we identify, pursue, and kill, capture or drive out the irreconcilables" (MNF-I Guidelines, reprinted in Ricks 2009, 369).

To sum up, there are at least three aspects to the civilianization of the armed forces: first, that the growing enmeshing of civilians within both national and subnational military groups renders the status-based principle of distinction conceptually more difficult to defend and pragmatically more difficult to follow. Second, in the context of counterterrorism and counterinsurgency, distinction (at least as it is interpreted by some governments and courts) already seems to move away from status-based classifications of status toward a determination of individual "guilt." In this sense, the human aspect of the principle of distinction is becoming more similar to the object aspect, which requires a case-by-case determination of the contribution of the intended target to the military effort. ${ }^{64}$ The third aspect is that this move from class-based to guilt-based determinations presumes an ability to make such individual determinations, which is the subject of the next section. After these determinations are possible, the justification for maintaining group-based decisions about targeting further diminishes. ${ }^{65}$

\subsection{Modern Technologies}

When governments undertake to engage in a case-by-case determination of the involvement of particular individuals in hostile activity, they must believe that they can do so. What makes it possible for military or other security forces to engage in such determinations and act upon them? More than anythingelse, it is the development and deployment of sophisticated intelligence-gathering

64 See supra note 34.

65 I ignore for present purposes the rejection of the principle of civilian immunity on the part of insurgents and terrorists, under a purportedly similar rationale. For the most part, this is a disingenuous claim, and in any case, it is hardly ever accompanied by individual-based distinctions but rather by indiscriminate attacks on populations, regardless of their role or function. 
and targeting technologies. While the human component of military intelligence remains as important as ever, the contributions of signal and visual intelligence to military decision-making are continuously increasing. The introduction of more intrusive and less visible technologies enables better remote-gathering and analysis of information in real time. Operational advances in communication, speedy deployment, and precision fire enable a more direct and immediate targeting.

All this advancement does not amount to perfect distinction in targeting; inadvertent civilian casualties are still abundant due to errors, miscalculation, malfunctioning, or mere indifference. Nor is modern technology omnipotent (Bin Laden is still at large). But the technology enables forces who care about minimizing civilian casualties to do so to some degree, even in theaters that make such distinctions highly complex, by identifying and firing at only those directly involved in hostile activity. The same technology that is currently used to tell civilians apart from combatants, and hostile civilians apart from the innocent, can be employed to distinguish among members of the armed forces to target only those who pose a real or immediate threat.

The technological revolution on the battlefield also makes for a growing disparity of power between warring parties on the modern battlefield. Although such disparities have always shaped the geopolitical map of the world (recall Athens' invasion of Melos), the gaps in military power and capabilities are growing, and with them the gaps in risk assumption on the battlefield. Technological advances enable combatants to strike targets from miles away and high above, exposing themselves to little or no risk of counterattack. Often, the target is unaware of the looming attack and is given no opportunity to surrender. A greater reliance on unmanned instruments (drones, robots, and the like) further diminishes the risks for those employing them. ${ }^{66}$

Asymmetries in power invite questions about fairness in war. Recall 101 Kahn's (2002) point about the unfairness of killing all combatants in grossly asymmetric wars. Fairness becomes a particularly hard issue when one considers the implications of the greater reliance on unmanned instruments: The fact that our machines are killing human beings on our behalf makes the dehumanization of soldiers even more striking. If there was ever an

66 Peter Singer (2009) reports that there currently are more than 5,300 drones in the U.S. inventory and about another 12,000 on the ground. 
element of fairness, of a "boxing match"-kind logic, it has been entirely lost once robots are doing the boxing for us. ${ }^{67}$

But even without inquiring about the underlying fairness of the current system, these developments do shed a different light on the application of the principle of military necessity on the battlefield. For powers that enjoy a substantial qualitative and quantitative advantage, it becomes more feasible and less risky to invest time and resources in determining the specific nature of targeted individuals. Leaders and commanders can be told apart from the rank and file, the highly trained pilots from the militarily insignificant cook, the armed from the unarmed, and so on. If so, it becomes less necessary to target all enemy combatants in the name of speedy victory and preservation of resources.

This argument does suggest that powers with greater capabilities might be held to stricter standards in complying with the laws of war. Although the normative legitimacy of a differentiated scale of compliance might be debated, as a positive matter, such differentiation already exists with regard to the protection of civilians. Weaker military or paramilitary forces already have every incentive, at times strategic, at other times ideological, to violate the laws of war. Stronger militaries with better technologies and more discriminatory capabilities are often expected by the international legal and humanitarian community to employ better precautions in conducting attacks and to minimize civilian casualties, under the intuition that "can" implies "ought" (Anderson 2009). For instance, in consideration of the rule prescribing taking precautions in attack to minimize civilian casualties, the more advanced militaries are expected to employ more discriminatory weapons ("smart bombs" and the like), even though these weapons are more expensive than ordinary munitions. As a matter of principle, then, "can" may imply "ought" with regard to enemy combatants' lives as well.

\section{AN ALTERNATIVE DOCTRINE}

The advantages of the current doctrines of military necessity and distinction lie in their purportedly straightforward application on the battlefield.

67 For a similar argument, see Kahn (2002, 3): "A regime capable of targeting and destroying others with the push of a button, with no human intervention but only the operation of the ultimate high tech weapon, propels us well beyond the ethics of warfare. Such a deployment of force may be morally justified - it might be used to promote morally appropriate ends—but we cannot appeal to the morality of warfare to justify this mode of combat." 
The current doctrines that permit the targeting of (almost) all combatants and ensure the immunity of (almost) all civilians allow military forces to make multiple determinations in a quick and self-protective manner, for simpler training of soldiers who ultimately have to apply the rule on the battlefield, and for more straightforward monitoring of compliance after the fact. ${ }^{68}$ To the degree these doctrines suffer from some elements of moral arbitrariness, a similar challenge could probably be raised against any alternative framework.

And still, given that human lives are at stake, there is reason to question whether the administrability of the current doctrines justifies the degree of their arbitrariness. This is particularly so since the application of the given doctrines on the modern battlefield is not as straightforward as the rules imply. Several classes of combatants are already exempt from targeting. These include the hors de combat, military chaplains, medical units, and civil defense forces. Civilians lose their immunity when they take direct part in hostilities. On the modern battlefield, which is often geographically undefined and where civilians and combatants coexist, attacking forces already have their work cut out for them: They must try to distinguish civilians from combatants (even where neither group wears uniforms), actively hostile civilians - a combined test of fact and judgment-from bystanders, and objects the disabling of which would contribute to the military effort from those that should be spared; they must also aim their weapons in a way that minimizes collateral harm to those immune. In other words, the nature of the modern battlefield both already calls for and enables an application of the principle of distinction in a way that departs from the crude combatant/civilian status-based distinction without prohibitively impairing the value of military necessity. More nuanced targeting decisions already require a substantial investment at the stage of application, limiting the advantage of the current rule-like doctrines over a more complex standard that would place further limits on the targeting of combatants. ${ }^{69}$

The problem of administrability of an amended targeting doctrine is nonetheless intertwined with several related difficulties. The first is that any change in the doctrine of distinction, especially one that narrows opportunities for targeting, is likely to raise the costs of lawful combat and of realizing

68 On the importance of clear guidance to soldiers on the battlefield, see Martha Minow (2007).

69 Here I follow Louis Kaplow's $(1992,560)$ distinction between rules and standards as "the extent to which efforts to give content to the law are undertaken before or after individual acts." 
the interest of military necessity, even beyond what the current complications of the modern battlefield call for. It would require some additional investment in intelligence gathering, target identification, precision fire, and even pretargeting legal advice. ${ }^{70}$ Second, a standard of targeting that relies on capabilities would apply differently to more advanced militaries than to the less sophisticated ones, potentially causing a moral hazard problem (such as avoiding investment in more discriminating technologies and weapons). Third, by its very nature, the realization of the standard would take different forms in different theaters of war. Fourth, regardless of a differentiated application depending on military capabilities or theater of war, the standard is likely to be followed by some while intentionally ignored by others. Fifth, the greater indeterminacy of a standard makes posthoc assessments - and particularly, potential criminal enforcement-less determinate too. This leads to the sixth problem, of the indeterminacy of a standard opening up opportunities for legal and political exploitation in the form of "lawfare," propaganda, and the like.

None of these problems should be dismissed or underestimated. But there are also mitigating aspects that should be pointed out: Conceptually, an amended standard would not be different from other limitations imposed by the rules of IHL, such as prohibitions on certain types of weapons or the need to spare civilians, which all add to the costs of lawful war. Adding further to these costs through a more complex targeting doctrine would be no different from agreeing on any other humanitarian constraint, beyond what the current law prescribes. Given that modern war-power allows the armed forces to be much more destructive at relatively lower costs than before, adding constraints to this destructive power is not unreasonable. Moreover, in consideration of the declining role of military power in determining the outcome of international disputes, constraints on the killing of enemy combatants might in fact create more incentives for warring parties to turn to alternative methods of resolving the conflict (negotiations, adjudication, economic incentives, and so on).

The prediction about asymmetrical compliance should similarly not serve as either a normative or a prescriptive block. Asymmetry is already prevalent with regard to the existing norm of distinction, as well as to other humanitarian rules of war-some forces comply with them, some ignore

70 See Kaplow $(1992,563,571-572)$, noting that legal advice in the case of standards is more costly than in the case of rules. 
them, and some manipulate them to their own advantage. Already, some militaries are held to higher standards of compliance by the media, public opinion, or international monitoring bodies than others, based on their capabilities. The moral hazard problem that exists today as a result of the status-based distinction doctrine will in all likelihood be replicated in different forms once the doctrine is amended; no doubt, parties that would seriously accept a more refined and complex legal targeting scheme might find themselves further disadvantaged by asymmetrical compliance. But, as in raising the costs of lawful war, concerns about asymmetrical compliance are present whenever any improvement of humanitarian protections is contemplated.

I nonetheless acknowledge that these mitigating factors might not be fully responsive to all the concerns noted earlier with regard to amending the targeting doctrine. Consequently, if and when the suggested amendments become impossible to apply without significantly raising the risk or costs to a party's ability to effectively prosecute its war, they would have to be forgone or reformed, as previous rules in the past have been. Ultimately, the decision whether to pursue them or not must rely on the value we want to assign the lives of human beings, including those of our enemies.

For these reasons, the proposals set forth are suggestive, rather than conclusive, intended more as examples of how we should rethink the existing paradigms on targeting combatants. In the face of uncertainty with regard to the operation of the proposed amendments, and given the unlikelihood of a broad political agreement over their adoption, a more phased and limited approach should be considered. Thus, there is a possibility for some armed forces to adopt a more restrictive targeting scheme as a unilateral selfimposed constraint (much in the same way that some military doctrinessuch as the revised U.S. military Counter-Insurgency Manual—call for more restrictive targeting schemes for the sake of safeguarding civilians, beyond what the laws of war mandate). In fact, if the call to demonstrate concern for enemy combatants has any traction, it is under the assumption that some armed forces can afford to absorb a certain degree of risk in exchange for caring for the enemy. It is also possible that moral, cultural, and aesthetic sensibilities would drive other militaries-although certainly not all fighting forces-to adopt similar doctrines. Whether or not these self-imposed restrictive doctrines would ultimately evolve into a binding legal norm is difficult to predict, and would probably depend on whether the changes in warfare earlier identified continue to characterize the modern battlefield. 
111 doctrines, which might be complementary to one another, and which strive to limit the terms and conditions of targeting enemy combatants. My focus is on the combatants' side of the equation of the principle of distinction, leaving aside the question of civilian immunity; this is so because civilian immunity is already at the center of moral, political, and legal debates about war, while the fate of combatants is marginalized. As I have noted in the introduction, it is possible to adopt these modified targeting schemes as complementary to the doctrine of civilian immunity, rather than as threats to it, with the outcome of reducing the direct targeting of human beings overall.

\subsection{From Status-Based to Threat-Based Determination: Rereading "Distinction"}

The first alternative framework calls for the relaxation of the status-based determination by supplementing it with an obligation to assess the individual threat emanating from any particular human target. This would require an amendment to the principle of distinction, from one separating combatants from civilians to one distinguishing threatening combatants from unthreatening ones. It is particularly striking that such a case-by-case determination is called for, in principle, for military objects but not for human beings. ${ }^{71}$

This amendment would essentially operate as the mirror-image of the doctrine of civilian immunity: Civilians are presumed innocent and immune unless and for such time as they take direct part in hostilities. ${ }^{72}$ The proposed change would make combatants presumptively dangerous, unless they pose no or marginal threat. After there is reason to believe that the level of threat is low, even if the enemy soldier is not hors de combat, the targeting forces would have to refrain from direct fire. A rebuttable mirrorpresumption about combatant targetability remains generally faithful to IHL's reliance on a status-based distinction, and stops short of a "policing model" test that would be based entirely on individual threat.

71 See supra note 35. eral damage. The point to emphasize here is that they should not be targeted intentionally, and that reasonable efforts to spare them should be made.

"Threat" in this context is not easily defined. The notion must be wider than in a classical self-defense paradigm (even though it is this paradigm

\footnotetext{
72 Art. 51(3) of API.
} 
that is so often employed to justify killing in war), but also narrower than the current understanding that allows the targeting of combatants on the assumption that they all have the potential to inflict damage. I employ the term "threat" here to denote something close to the "guilt" or "involvement" test that has been employed by governments in the war on terrorism. Three dimensions of possible threat are role, time, and geography.

As a general matter, it is possible that the application of each of these dimensions would depend on some subjective psychological perception of the concept of "threat," which is hard to prescribe for or to pass judgment over. Zealous ideological/religious terrorists might be seen by one military commander as more threatening than a soldier in the Iraqi army, making the former targetable even while swimming in the lake, and the latter a life we can spare. As in the case of the civilian who takes direct part in hostilities, the determination of threat would require a factual determination (characteristics of the individual target) as well as a judgment call (the degree to which these characteristics pose a threat).

\subsubsection{Role}

Threat might be a function of role. For instance, a military cook's contribution to the war effort, despite Napoleon's famous observation, is minimal. In fact, in many armed forces billeting has been outsourced to private contractors for exactly the reason that one requires no military training in order to be a cook. The irony here is that under the existing status-based distinctions, the military cook is targetable, while the one working for the KBR company is probably not as he or she would not meet the "direct participation" standard (Third Expert Meeting on the Notion of Direct Participation in Hostilities 2005). A useful way to test the presumption about threat might therefore be to ask whether the role played by the individual soldier is essentially a military one, or whether it is of the type often played by civilians who do not meet the "direct participation" standard. Naturally, the more militaries become reliant on civilians even for traditional "military" functions, such as those performed by Blackwater in Iraq, the less this form of rebuttal is useful. Still, soldiers who play roles and functions that have a clear civilian corollary, and which in their civilian corollary do not give rise to loss of immunity, should be spared. Such roles would include, among others, military spokespersons, judge advocate general officers, bandspersons, financial management personnel, military police officers, and so on. It is rare that soldiers performing these roles should take an active part in 
combat. Their exclusion from direct attack would follow a similar logic to the protection accorded to medical units, military chaplains, or military personnel assigned to civil defense units. Of course, in different militaries various units might be assigned different roles (for instance, in some armies, military police takes an active part in the fighting), so that the role distinction would have to depend on the particular structure of the enemy forces.

Although role distinctions are certainly less bright than the soldier/ civilian line (provided, that is, that soldiers are wearing uniforms), they are not impossible to make. In many military contexts distinctions between combat, combat-support, or combat-service roles already exist, such as in differentiated salary payment (for instance, through special compensation for combat role or training level) or in military deployment plans. To make such distinctions obvious to an outside observer (who should presumably base his targeting decisions on them), differentiation also exists in military dress: There are different markings for different ranks, some units have their own colored berets (for example, the "Green Berets"), and the various services all have their own sets of uniforms (U.S. Dept. of the Army 2005); it is not inconceivable to think about different military dress that would correspond to combat/noncombat roles. ${ }^{73}$ To the extent that soldiers can cheat and wear different-colored berets or uniform, they can also cheat by disguising themselves as civilians.

From a legal standpoint, this change would require a reinterpretation of Article. 43 of API (which states that members of the armed forces are "combatants"), in differentiating soldiers who are clearly not serving in any combat role from those who are. In this sense, the 1907 formulation in the Hague Regulations that did distinguish among members of the armed forces in combat role and those who were not should be revived.

I do not suggest a distinction between conscripted and volunteer soldiers. Although I follow Walzer's ([1977] 2006, 138-145) moral distinction between those who have been coerced to fight and those who seek fighting as a profession, I also agree with his ultimate conclusion that members of both groups might be equally threatening. ${ }^{74}$ In departing from Walzer, individual members of both groups might be unthreatening.

73 This proposal was raised by Kasher (2009a, 24).

74 In his discussion of “The Status of Individuals," Walzer does not make any distinction between targeting conscripts and targeting volunteer soldiers or mercenaries. See also Coady's (2008, 167) description of a pre-battle speech delivered by a British military commander in Iraq, Col. Tim Collins, to his troops, ordering them to distinguish between those who "have resolved to fight and others [who] wish to survive." 


\subsubsection{The Temporal Dimension}

"Threat" might depend on an individual's ability to cause harm at a particu121 lar moment; thus, a military pilot is undoubtedly contributing to the war effort, but not while he is sleeping, bathing, playing soccer, or on leave. This temporal test is trickier than the role one, as the individual resumes his threatening stance once back on duty. But taken ad absurdum, any person (including children) might become dangerous at a later point, either by joining the armed forces or by taking direct part in hostilities. Walzer's presumption-that the soldier "allowed himself to become a dangerous man"-is simply unconvincing at a moment in which a particular soldier is clearly not dangerous.

Adopting a temporal test for "threat" would require moving away even further from bright-line rules of status or even role toward a standard of reasonableness. It will also require consideration of the possibilities of preventing the threat from materializing at some later point.

One limitation of a standard of reasonableness appears as one considers the temporal test of threat as applied for civilians-turned-combatants under Article 51(3). To recall, the Israeli High Court of Justice interpreted the text "for such time" in an expansive manner, rejecting the notion of a "revolving door" (for example, the frequent change in status from civilian to combatant and back to civilian again). After sufficient ties were formed between the civilian and the hostile activity, the civilian could be attacked even when he was not taking part in hostilities at that particular time, a position contested by some experts (Melzer 2009, 65-67). Any temporal test adopted for combatants must ensure that we do not reach an absurd result by which the bathing soldier cannot be attacked, while the bathing civilian can.

A particularly complicated case for the temporal test is that of retreating soldiers. Although soldiers in retreat are currently fair game, a temporal test of threat may impose limitations on the legitimacy of targeting them, even if they might become threatening at some later point. The argument against such limitations is obvious-the retreating soldiers choose not to surrender, but instead to rearm and regroup and possibly return to the battle zone better-equipped and better-prepared. But there are valid arguments in favor of limiting the permissible killing of retreating soldiers. One is that it is possible these soldiers would not return to the battle zone or that the war will end before they do so. This is particularly so if one considers the rising importance of alternative factors and forces in bringing a conflict to an end. Another reason is the intuition of unfairness, as expressed by Kahn and 
others. This intuition, although resonating of deontological sensibilities, is not necessarily devoid of strategic consequences. Consider, for instance, the "Highway of Death" incident: On the night of February 26-27, 1991 (and then again, on March 2), U.S. airplanes struck an Iraqi convoy on Highway 80, leading from Kuwait City to Basra. The strikes resulted in the deaths of hundreds of retreating Iraqi soldiers. The convoy retreat was highly welcomed by the American forces:

Now, it is almost like you flipped on the light in the kitchen late at night and the cockroaches start scurrying and we are killing them... . The long wait for the Iraqis to come up and fight has finally come to an end... . They are moving in columns; they are moving in small groups and convoys. It is exactly what we have been looking for and it looks to me like Saddam has lost his marbles (Walker 1991). ${ }^{75}$

Human-rights groups, on the other hand, were outraged. Kenneth Roth, deputy director of Human Rights Watch at the time, argued: "It wasn't a tactical retreat... It was a panicked, desperate flight and these were just lowly soldiers trying to get the hell out of there. It appears that this was a case of senseless slaughter" (Waller \& Barry 1992, 16).

Under the existing rules, the Highway of Death was a lawful military action, despite Roth's protest; it is only if a temporal limitation on "threat" were to be adopted that the legitimacy of the "turkey shoot" would be questionable. Ultimately, however, and despite the formal legality of the strikes, the images of the carnage generated such public uproar that the U.S. leadership was forced to cease its military campaign soon afterwards (Evans 1991).

Of course, one could argue that by contributing to the war's speedy end, the incident might have ultimately saved more lives than had the convoys been spared and the war been allowed to continue. But there are two responses to this argument: One is that "we got the wrong people" (killing the beat-up retreating soldiers instead of continuing a campaign against the higher military or political leadership, the Republican Guard, the weapons developers, and so on); the other is that this type of strict-utilitarian argument is both impossible to assess and quickly collapses any type of humanitarian constraint on warfare.

What is also interesting to note about the Highway of Death incident is that the decision to attack the retreating soldiers was not made by low-level

75 Words of Lieutenant-Colonel Dick "Snake" White, commander of the Tomcat Squadron of U.S. Harrier. 
officers on the ground, but by the top echelons of the American military. In that sense, concerns about excessive discretion - and responsibility - of young soldiers who would have to apply complex targeting doctrines are less acute when large numbers of enemy troops are concerned.

\subsubsection{The Geographical Dimension}

Finally, "threat" might have a geographical component, which together with the temporal dimension might further help to define the concept of threat. A soldier bathing near his post is more threatening than the one bathing in a remote lake, and a soldier playing soccer on a military base is probably more dangerous than the one playing soccer in a civilian neighborhood. This lower degree of threat has not been considered any impediment for legitimate targeting. In the case of the Prosecutor v. Galic, Bosnian Serb forces were accused of indiscriminate targeting when they shelled rounds at a group of the Army of Bosnia-Herzegovina forces playing football in a makeshift field in a parking lot in the neighborhood of Dobrinja, Sarajevo. About 200 civilian spectators were watching the game. As a result of the shelling, more than ten soldiers and civilian spectators were killed and over a hundred were injured. In finding the defendants guilty, the International Criminal Tribunal for the Former Yugoslavia stated:

Although the number of soldiers present at the game was significant, an attack on a crowd of approximately 200 people, including numerous children, would clearly be expected to cause incidental loss of life and injuries to civilians excessive in relation to the direct and concrete military advantage anticipated. $^{76}$

The crime, therefore, was the killing of civilians, not of soldiers who were clearly off duty, playing football, unarmed, and unthreatening. What makes these playing soldiers so different from the civilian spectators who were watching them play football is unclear, other than the fact that they have military training and return to the fray. Which brings us back to the temporal dimension of "threat" and to the question whether a potential threat that might (or might not) materialize at some later point in time justifies killing here and now. Neither the geographical dimension nor the temporal aspect of the concept of threat is compatible with the deliberate killing of soldiers playing soccer in an improvised field. 
131 different applications to different theaters of war. American forces fighting a "global war on terrorism" might deny any geographical dimension to the concept of threat, while Russian forces targeting Chechen separatists will be more constrained in defining the theater of war. These dimensions of threat also vary with capabilities: Technologically advanced armies, which can plan and execute military operations from a great distance in real time, are less exposed to threat than less sophisticated forces that are more geographically concentrated and whose movement is slower. In those cases, "front" and "rear" become increasingly difficult to distinguish, as the operator of a predator drone might be many miles away from the drone itself. Particularly, where drones or other robots are deployed, the concept of threat becomes harder to apply, because the questions of "threat to whom" or "to what" become more difficult to answer.

\subsection{From Shoot-to-Kill to Kill-When-Necessary: Rereading "Military Necessity"}

Nothing in the current laws of war requires combatants to exercise restraint when targeting enemy forces: They are not obliged to injure instead of kill or capture instead of injure. As the ICRC acknowledged in its Interpretive Guidance on Direct Participation in Hostilities:

Clearly, the fact that a particular category of persons is not protected against offensive or defensive acts of violence is not equivalent to a legal entitlement to kill such persons without further considerations. At the same time, the absence of an unfettered "right" to kill does not necessarily imply a legal obligation to capture rather than kill regardless of the circumstances (Melzer 2009, 78).

In a footnote, the ICRC added the following caution:

It is in this sense that Pictet's famous statement should be understood that "[i]f we can put a soldier out of action by capturing him, we should not wound him; if we can obtain the same result by wounding him, we must not kill him. If there are two means to achieve the same military advantage, we must choose the one which causes the lesser evil”.... (Melzer 2009, fn. 221).

Although citing Pictet with agreement, the ICRC was then forced to concede:

During the expert meetings, it was generally recognized that the approach proposed by Pictet is unlikely to be operable in classic battlefield situations involving large scale confrontations ... and that armed forces operating in 
situations of armed conflict, even if equipped with sophisticated weaponry and means of observation, may not always have the means or opportunity to capture rather than kill... (Melzer 2009, fn. 221).

Clearly, Pictet's call for the exercise of less-harmful means does not reflect the customary interpretation of the laws of war, nor is it suggested in any military manual instructing soldiers on battlefield conduct. In fact, the attempt by the ICRC to introduce the less-harmful-means test as part of the principle of military necessity has been rejected by the expert group meeting, not only, as the previous footnote from the Interpretive Guidance seems to suggest, for large-scale confrontations, but as a limiting feature of the principle of military necessity altogether.

But why should a less-harmful-means test not be a feature of the principle of military necessity? Certainly, fighting forces already decide where and how to invest resources in the most efficient and effective way, operating under a perpetual resource constraint. However, the current interpretation of "necessary" as including what is less costly or less risky or even merely convenient allows too broad a discretion for forces to attack available — rather than clearly "necessary" - targets. To bring the term "necessary" closer to its literal meaning, it should include a least-harmful means component; it is entirely possible to conceive of "necessary" as the least measure of harm by which to achieve a desired end. If the end might be achieved by incapacitating the enemy without killing him, then that is what "necessary" should mean. If so, attacking forces should prefer capture to killing, wherever feasible. And although feasibility might depend on tactical capabilities in a particular time and place, it is unclear why it should be ruled out altogether from "classic battlefield situations involving large scale confrontations."

A first move toward bringing "necessity" closer to its ordinary meaning has been made by the Israeli Supreme Court, which in the aforementioned decision on targeted killing ruled that when there was a feasible alternative of arrest, the government must exercise that alternative and refrain from killing. As commentators have noted, this requirement was not based on the existing laws of war, either with regard to civilians or combatants (Cohen \& Shany 2007). Rather, it was introduced under a domestic constitutional principle of proportionality. In essence, it was an expression of the court's uneasiness about the full implications of a "war on terror" paradigm and its backlash toward a law-enforcement model, in which the use of lethal force must be a last resort. In this sense, the Court followed Kahn's (2002) move of importing policing doctrines into the laws of armed conflict. 
Another move in this direction has been the research and development into nonlethal weapons (NLW) and the employment of police-like NLW in various theaters of conflicts. In fact, the U.S. defense establishment (military and Department of Defense) is an active promoter of the research into and development of NLW (Allison, Kelley, \& Garwin 2004, 3; Global Security 2009). Originally, interest in less-than-deadly weapons arose from the military's deployment to nontraditional theaters, including humanitarian interventions or military operations other than war. But this interest seems to have expanded beyond riot-control or law-and-order operations in complex environments, to include potential wartime capabilities, such as putting to sleep or stunning combatants, in more traditional settings (Allison, Kelley, \& Garwin 2004, 9-10). If NLW prove effective, the question becomes why it is necessary to employ lethal means, unless there is independent value in actually killing combatants.

Another different manifestation of a less-harmful-means test would be favoring the targeting of military objects over military personnel. For instance, if one party has the opportunity to disable enemy aircraft, vehicles, munitions, supplies, and so on, it should do so with preferably as few-rather than as many-human casualties (military and civilian) as possible. After the tools of war are destroyed, it would become easier to capture or otherwise disable enemy combatants without having to kill them (Roberts 2008, 960).

Of course, capturing enemy combatants imposes costs and burdens on the captor in terms of holding, transferring, and catering to the captives (the military, political, and legal costs of holding enemy combatants in Guantanamo Bay create a strong incentive to kill rather than capture); an advance warning might alert the enemy and allow it to better prepare for the attack; and stunned combatants might return to combat activity once the effects of the nonlethal strike wear off. But IHL already requires warring parties to assume certain burdens: It prohibits announcing that no quarter shall be given and orders the holding, transferring, and catering to captured or surrendering POWs; it prohibits the use of certain weapons that cause superfluous injury and unnecessary suffering; and it does not allow breaking any of these rules in the name of military necessity.

Ultimately, as in the case of an amended doctrine of distinction, the question must be whether adding a less-harmful means condition to the interpretation of the principle of military necessity imposes such burdens as to fundamentally break the balance struck by current IHL between the necessities of war and humanitarian concerns. This question might undoubtedly 
vary from one battlefield to another, and different combat scenarios would allow-or restrict - the application of a capture-alternative. But ultimately, it would depend on the human value we choose to assign to the lives of combatants.

\section{CONCLUSION}

It is the fate of the civilian harmed by war that has been the focus of international law's attention ever since the end of World War II, and which has shaped the rhetoric and consciousness of those concerned with war. The term "enemy civilians" has been taken out from the Army Field Manuals, leaving only the generic protected class of "civilians." International human rights activists consistently campaign on behalf of civilians affected by war, alongside the International Committee of the Red Cross that provides them with humanitarian assistance. An entire body of crimes against humanity has developed to supplement an older body of war crimes, with the well-being of civilians in mind. Whether or not enemy civilians are actually better off today than they were in past times is debatable, but they are undoubtedly entitled to greater protections as a matter of law.

The fate of combatants fighting wars has benefitted far less from these developments. As far as combatants are concerned, the laws and customs of war have changed very little since the Civil War, especially for those who are not hors de combat, adding some limitations on the types of weapons that may be used to kill but not on killing as such. Drew Faust $(2008,42)$ has described the dismayed attitude of Confederate soldiers toward Union sharpshooters: "To shoot a man as he defecated, or slept, or sat cooking or eating, or even as he was 'sitting under a tree reading Dickens,' could not easily be rationalized as an act of self-defense. Soldiers in camp wanted to think themselves off duty as targets as well as killers, and they found the intentionality and personalism involved in picking out and picking off a single man highly disturbing."

And yet this sharpshooting was perfectly legal during the Civil War; more remarkably, it is still so today.

The question why we should treat combatants any differently from civilians on the battlefield largely depends on the values we want our system of laws of war to promote. Our current system of IHL sacrifices soldiers in the name of protecting civilians. It is an extension of the dueling system, whereby we send a group of soldiers to fight another group of soldiers, 
and the outcome of that fight determines the fate of compatriot civilians. Soldiers are thus instruments of war. We dress them up in uniform and that uniform defines them as instruments and obliterates their individual identity. $^{77}$

In an international system that is state-centered, the dueling logic might persist in the face of any liberal individualistic commitments. As our system changes, the status of the dueling system might grow more precarious. For now, though, any amendment that departs from a rule-based right toward a standard-based judgment faces several difficulties, including asymmetries in compliance, more complex administrability, and potential for military and political exploitation. These are all real and substantial challenges, even if not conceptually or fundamentally different from other limitations on lawful warfare. Ultimately, the recognition of soldiers' noninstrumental human value might require absorption of some degree of enhanced risk or cost to the enterprise of war.

Attempts at an amended reading of the principles of military necessity and distinction or a narrowed interpretation of the definition of "combatants" have so far been met with resistance. But such attempts have been sparse and distant from the focus of the international humanitarian community's attention. Geopolitical, normative, and technological advances, which have all shaped and reshaped the laws of war throughout history, make these attempts worthy and possible of success today. There is no reason to reject them as improbable or unrealistic - at least, not more than banning anti-personnel landmines, or prohibiting the use of physical pressure in interrogating POWs, or requiring warring parties to show concern for the environmental impact of military operations. The laws of war change as public preferences and sensibilities call them to. They might very well change further to reflect a growing care for the enemy, even enemy combatants. 


\section{REFERENCES}

Abresch, William. 2005. The Human Rights Law of Internal Armed Conflict: The European Court of Human Rights in Chechnya. 16 Eur. J. Int'l L. 741-767.

Alexander, Keith. 2009. Cyberspace as a Warfighting Domain: Policy, Management and Technical Challenges to Mission Assurance. Hearings before the Subcommittee on Terrorism, Unconventional Threats and Capabilities, of the House Armed Services Committee, 111th Cong., 1st Sess. 3.

Alexander, Lawrence A. 1976. Self-Defense and the Killing of Noncombatants: A Reply to Fullinwider. 5 Phil. \& Pub. Aff. 408-415.

Allison, Graham T., Paul X. Kelley, \& Richard L. Garwin. 2004. Nonlethal Weapons and Capabilities. Report of an Independent Task Force Sponsored by the Council on Foreign Relations. Available at: http://www.fas. org/rlg/040000-nonlethal.pdf.

Anderson, Kenneth. 2002. What to Do with Bin Laden and Al Qaeda Terrorists? A Qualified Defense of Military Commissions and United States Policy on Detainees at Guantanamo Bay Naval Base. 25 Harv. J. Law \& Pub. Pol'y 593-634.

- 2007. U.S. Counterterrorism Policy and Superpower Compliance with International Human Rights. 30 Fordham Int'l L. J. 455-484.

- 2009. The Rise of International Criminal Law: Intended and Unintended Consequences. 20 Eur. J. Int'l L. 331-358.

Anscombe, Elizabeth. 1970. War and Murder. In Richard A. Wasserstrom, ed., War and Morality. 42-53. Belmont, CA: Wadsworth.

Avant, Deborah, \& Lee Sigelman. 2008. What Does Private Security in Iraq Mean for Democracy at Home? Available at: http://www.international. ucla.edu/cms/files/PrivateSecurityandDemocracy.pdf.

Balendra, Natasha. 2008. Defining Armed Conflict. 29 Cardozo L. Rev. 2461-2516.

Berman, Nathaniel. 2004. Privileging Combat? Contemporary Conflict and the Legal Construction of War. 43 Colum. J. Transnat'l L. 1-71.

Best, Geoffrey. 1983. Humanity in Warfare. London: Methuen \& Co.

Bialke, Joseph P. 2004. Al Qaeda \& Taliban Unlawful Combatant Detainees, Unlawful Belligerency and the International Laws of Armed Conflict. 55 A. F. L. Rev. 1-85.

Blum, Gabriella. 2010. The Laws of War and the Lesser Evil. 35 Yale J. Int'l L. 1-69. 
Bobbitt, Philip. 2002. The Shield of Achilles: War, Peace, and the Course of History. New York: Knopf.

Boettcher, William A. III, \& Michael D. Cobb. 2006. Echoes of Vietnam? Casualty Framing and Public Perceptions of Success and Failure in Iraq. $50 \mathrm{~J}$. Conflict Res. 831-854.

Braudy, Leo. 2005. From Chivalry to Terrorism: War and the Changing Nature of Masculinity. New York: Vintage Books.

Christopher, Paul. 2004. The Ethics of War and Peace: An Introduction to Legal and Moral Issues. Upper Saddle River, NJ: Pearson/Prentice Hall.

Coady, C. A. J. (Tony). 2004. Terrorism and Innocence. 8 J. Ethics 37-58. 2008. The Status of Combatants. In David Rodin \& Henry Shue, eds., Just and Unjust Warriors: The Moral and Legal Status of Soldiers. 153-175. Oxford: Oxford University Press.

Cohen, Amichai, \& Yuval Shany. 2007. A Development of Modest Proportions: The Application of the Principle of Proportionality in the Targeted Killing Case. 5 J. Int'l Crim. Just. 310-321.

Colvin, Marie, Tony Allen-Mills, \& Uzi Mahnaimi. 2008. Israeli Strike Kills “At Least 225" in Strikes on Gaza, Times Online, December 28.

Cunningham, G. K. 2008. Landpower in Traditional Theory and Contemporary Application. In J. Boone Bartholomees, Jr., ed., vol. 1 of U.S. Army War College Guide to National Security Issues. 107-128. Carlisle Barracks, PA: Strategic Studies Institute, U.S. Army War College.

De Chateaubriand, François-René. 1814. De Buonaparte et des Bourbons. London.

Dinstein, Yoram. 2007. The System of Groups in International Humanitarian Law. In Wolff Heintschel von Heinegg \& Volker Epping, eds., International Humanitarian Law Facing New Challenges: Symposium in the Honour of Knut Ipsen. 145-156. Berlin: Springer.

Elting, John Robert. 1988. Swords Around a Throne: Napoleon's Grand Armée. New York: Da Capo.

Evans, Michael. 1991. The Final Turkey Shoot, The Times, March 27.

Faust, Drew Gilpin. 2008. This Republic of Suffering. New York: Knopf.

Ford, John C. 1970. The Morality of Obliteration Bombing. In Richard A.

Wasserstrom, ed., War and Morality. 15-41. Belmont, CA: Wadsworth.

Fremont-Barnes, Gregory, \& Todd Fisher. 2004. The Napoleonic Wars: The

Rise and Fall of an Empire. Oxford: Osprey.

Fullinwider, Robert K. 1975. War and Innocence. 5 Phil. \& Pub. Aff. 90-97. 
Gat, Azar. 2009. Victorious and Vulnerable: Why Democracy Won in the 20th Century and How It Is Still Imperiled. Lanham, MD: Rowman \& Littlefield.

Global Security. 2009. Non-Lethal Weapons. Available at: http://www. globalsecurity.org/military/systems/munitions/non-lethal.htm.

Goodman, Ryan. 2009. Editorial Comment: The Detention of Civilians in Armed Conflict. 103 A.J.I.L. 48-74.

Graves, Robert. 1929. Good-bye to All That. London: J. Cape.

Green, Michael. 1992. War, Innocence, and Theories of Sovereignty. 18 Soc. Theory \& Prac. 39-62.

Green, Thomas Hill. 1895. Lectures on the Principles of Political Obligation. London: Longmans, Green, \& Co.

Greenwood, Christopher. 2000. The Applicability of International Humanitarian Law and the Law of Neutrality to the Kosovo Campaign. In Yoram Dinstein \& Fania Domb, eds., vol. 30 of The Israeli Yearbook on Human Rights. 111-144. The Hague: Martinus Nijhoff.

Grier, Peter. 2008. Record Number of US Contractors in Iraq, Christian Sci. Monitor, August 18.

Heidenrich, John G. 1993. The Gulf War: How Many Iraqis Died? Foreign Pol'y, March 22.

Hobbes, Thomas. [1640] 1999. The Elements of Law: Natural and Politic. J.C.A. Gaskin, ed. Oxford: Oxford University Press.

Holmes, Robert. 1989. On War and Morality. Princeton: Princeton University Press.

Howard, Michael, George J. Andreopoulos, \& Mark R. Shulman, eds. 1994. The Laws of War: Constraints on Warfare in the Western World. New Haven: Yale University Press.

Issacharoff, Samuel. 2009. Political Safeguards in Democracies at War. 29 Oxford J. Legal Stud. 1-26.

Jinks, Derek, \& David Sloss. 2004. Is the President Bound by the Geneva Conventions? 90 Cornell L. Rev. 97-202.

Kahn, Paul. 1999. War and Sacrifice in Kosovo. 19 Phil. \& Pub. Pol'y Quart. Available at: http://www.publicpolicy.umd.edu/IPPP/spring summer99/kosovo.htm.

- 2002. The Paradox of Riskless Warfare. 22 Phil. \& Pub. Pol'y Quart. 2-8.

Kaldor, Mary. 2006. New and Old Wars. Cambridge: Polity Press. 
Kaplow, Louis. 1992. Rules Versus Standard: An Economic Analysis. 42 Duke L. J. 557-629.

Kasher, Asa. 2009a. A Combatant's Life and Human Dignity: A Plea for a Major Change. Draft, on file with author.

- 2009b. The Gaza Campaign and the Ethics of Just War. 37 Azure 55-86.

Kennedy, David. 2006. Of War and Law. Princeton: Princeton University Press.

Kutz, Christopher. 2005. The Difference Uniforms Make: Collective Violence in Criminal Law and War. 33 Phil. \& Pub. Aff. 148-180.

Lindemann, Marc. 2007. Civilian Contractors under Military Law. 37 Parameters 83-94.

Mandel, Robert. 2006. The Meaning of Military Victory. Boulder: Lynne Rienner.

Manero, David G. 2007. Military Transition to Contractors: Are We Getting Less for Less? Research Report, Air War College.

Mavrodes, George I. 1975. Conventions and the Morality of War. 4 Phil. \& Pub. Aff. 117-131.

May, Larry. 2007. War Crimes and Just War. Cambridge: Cambridge University Press.

McKeogh, Colm. 2007. Civilian Immunity in War: Augustine to Vattel. In Igor Primoratz, ed., Civilian Immunity in War. 62-83. Oxford: Oxford University Press.

McMahan, Jeff. 2006. On the Moral Equality of Combatants. 14 J. Pol. Phil. 377-393.

Melzer, Nils. 2009. Interpretive Guidance on the Notion of Direct Participation in Hostilities Under International Humanitarian Law. Reference Report of the Int'l Comm. Red Cross. Available at: http://www.icrc.org/ Web/eng/siteeng0.nsf/htmlall/direct-participation-report_res/\$File/ direct-participation-guidance-2009-icrc.pdf.

Minow, Martha. 2007. Living Up to Rules: Holding Soldiers Responsible for Abusive Conduct and the Dilemma of the Superior Orders Defence. 52 McGill L. J. 1-54.

Nagel, Thomas. 1972. War and Massacre. 1 Phil. \& Pub. Aff. 123-144.

NATO. 2009. Glossary of Terms and Definitions, AAP-6. Available at: http:// www.nato.int/docu/stanag/aap006/aap-6-2009.pdf.

Neff, Stephen. 2005. War and the Law of Nations: A General History. Cambridge: Cambridge University Press. 
Palmer-Fernandez, Gabriel. 2000. Innocence in War. 14 Int'l J. Applied Phil. 161-174.

Parks, W. Hayes. 1989. Memorandum of Law: Executive Order 12333 and Assassination. Department of the Army Pamphlet 27-50-204.

- 2007. Asymmetries and the Identification of Legitimate Military Objectives. In Wolff Heintschel von Heinegg \& Volker Epping, eds., International Humanitarian Law Facing New Challenges: Symposium in Honor of Knut Ipsen. 65-116. Berlin: Springer.

Peebles, Curtis. 2005. Twilight Warriors: Covert Air Operations Against the USSR. Annapolis: Naval Institute Press.

Pictet, Jean. 1952. Commentary: I Geneva Convention for the Amelioration of the Condition of the Wounded and Sick in Armed Forces in the Field. Geneva: International Committee of the Red Cross.

Pilloud, Claude, Jean de Preux, Yves Sandoz, Bruno Zimmerman, Philippe Eberlin, Hans-Peter Gasser, Claude F. Wenger, Sylvie-S. Junod, \& Jean Pictet. 1987. Commentary on the Additional Protocols of 8 June 1977 to the Geneva Conventions of 12 August 1949. Yves Sandoz, Bruno Zimmerman, \& Christophe Swinarski, eds. Geneva: International Committee of the Red Cross.

Pontrelli, Christopher. 2007. The Butchers of Kapsan, Naval History, October. Primoratz, Igor. 2002. Michael Walzer's Just War Theory: Some Issues of Responsibility. 5 Ethical Theory \& Moral Prac. 221-243.

Ramsey, Paul. 1968. The Just War: Force and Political Responsibility. New York: Scribner.

Reynolds, Clark G. 2005. On the Warpath in the Pacific. Annapolis: Naval Institute Press.

Ricks, Thomas E. 2009. The Gamble: General David Petraeus and the American Military Adventure in Iraq, 2006-2008. New York: Penguin Press.

Roberts, Adam. 2008. The Equal Application of the Laws of War: A Principle Under Pressure. 90 ICRC Rev. 931-962.

Rogers, A. P. V. 2000. Zero-Casualty Warfare. 837 Int'l Rev. Red Cross. 165-181. Sanger, David E., John Markoff, \& Thom Shanker. 2009. U.S. Plans Attack and Defense in Web Warfare, N.Y. Times, April 28.

Sassòli, Marco. 2006. Terrorism and War. 4 J. Int'l Crim. Justice 959-981.

Schmitt, Michael N. 2008. Asymmetrical Warfare and International Humanitarian Law. 62 A. F. L. Rev. 1-42.

Shue, Henry. 1978. Torture. 7 Phil. \& Pub. Aff. 124-143.

Singer, Peter W. 2009. America’s Killing Machine, L.A. Times, January 30. 
Smith, Rupert. 2005. The Utility of Force: The Art of War in the Modern World. London: Allen Lane.

Stacey, Robert C. 1994. The Age of Chivalry. In Michael Howard, George J. Andreopoulos, \& Mark R. Shulman, eds., The Laws of War: Constraints on Warfare in the Western World. New Haven: Yale University Press.

Steinhoff, Uwe. 2007. Civilians and Soldiers. In Igor Primoratz, ed., Civilian Immunity in War. 42-61. Oxford: Oxford University Press.

Strickland, Matthew. 1996. War and Chivalry: The Conduct and Perception of War in England and Normandy, 1066-1217. Cambridge: Cambridge University Press.

Third Expert Meeting on the Notion of Direct Participation in Hostilities. 2005. Summary Report. Available at: http://www.icrc.org/Web/eng/ siteeng0.nsf/htmlall/participation-hostilities-ihl-311205/\$File/Direct_ participation_in_hostilities_2005_eng.pdf.

UK Ministry of Defence. 2004. The Manual of the Law of Armed Conflict, Section 2.2 (Military Necessity). Oxford: Oxford University Press.

U.S. Congressional Budget Office. 2008. Contractors' Support of U.S. Operations in Iraq, Pub. No. 3053. Washington, D.C.: Government Printing Office.

U.S. Department of the Army. 1956. Field Manual 27-10, $\$ 3$.

-2000. Field Manual 27-100, Legal Support to Operations. March 1.

-2003. Field Manual 7-21.13, The Soldier's Guide. October 15.

- 2005. Wear and Appearance of Army Uniforms and Insignia. Army Regulation 670-1. February 3.

U.S. Department of the Navy. 2007. The Commander's Handbook on the Law of Naval Operations, NWP 1-14M/MCWP 5-12-1/COMDTPUB P5800.7A, § 5.3.1.

Walker, Christopher. 1991. Allied Pilots Queue up for 'Turkey Shoot' in the Desert, The Times, February 2.

Waller, Douglas, \& John Barry. 1992. The Day We Stopped the War, Newsweek, January 20.

Walzer, Michael. [1977] 2006. Just and Unjust Wars. New York: Basic Books.

Zohar, Noam. 1993. Collective War and Individualistic Ethics: Against the Conscription of "Self-Defense." 21 Pol. Theory 606-622.

- 2004. Innocence and Complex Threats: Upholding the War Ethic and the Condemnation of Terrorism. 114 Ethics 734-751.

Zupan, Daniel S. 2004. War, Morality, and Autonomy: An Investigation into Just War Theory. Burlington, VT: Ashgate. 